2614 六フッ化イオウ水溶液の電気伝導度 測定によるパルス放射線分解。四フッ

$[3 \cdot 2]$ 化イオウの加水分解速度

Conductometric Pulse Radiolysis of Sulfur Hexafluoride in Aqueous Solutions. Rate of Hydrolysis of Sulfur Tetrafluoride

K.D. Asmus, W. Grünbein and J.H. Fendler:

J. Am. Chem. Soc., 92, (9) 2625 28 (1970)

$\mathrm{SF}_{6}$ 約 $2 \times 10^{-4} M$ の中性水溶液に打いて伝導度は 2 段 階で增加し全体の約 $25 \%$ がパルス中 $(\sim 0.3 \mu \mathrm{sec})$ に, そして残りの部分は一次過程で約 $1 \mathrm{msec}$ 後に完結し た。この場合の当量伝導度のパルス照射による全増加 量は $2,700 \mathrm{~cm}^{2} \mathrm{ohm}^{-1}$ となり, 既知の各種当量伝導度 を用いるとつぎの反応過程で説明することができる。

$\mathrm{H}_{2} \mathrm{O}-\mathrm{W} \rightarrow e_{a q}^{-}+\mathrm{H}_{3} \mathrm{O}^{+}$, etc., $e_{a q}^{-}+\mathrm{SF}_{6} \stackrel{\mathrm{H}_{2} \mathrm{O}, \mathrm{OH}}{\longrightarrow} 6 \mathrm{~F}^{-}$

$+\mathrm{SO}_{4}^{2-}+7 \mathrm{H}_{3} \mathrm{O}^{+}$

最初の $25 \%$ の速い立ち上がり部分は水和電子の 60
$70 \%$ $\mathrm{SF}_{6}$ に捕捉されると仮定した場合の当量伝導度 の変化括よび水和電子の光学的吸収の消滅過程との同 時性などから, $\mathrm{SF}_{6}+e_{a q}^{-} \longrightarrow \cdot \mathrm{SF}_{5}+\mathrm{F}^{-}, \cdot \mathrm{SF}_{5}+2 \mathrm{H}_{2} \mathrm{O}$ $\longrightarrow \mathrm{OH}+\mathrm{F}^{-}+\mathrm{H}_{3} \mathrm{O}^{+}+\mathrm{SF}_{4}$ なる過程に対応すると考兄 られる。 $k_{4}>6.3 \times 10^{3} \mathrm{M}^{-1} \mathrm{sec}^{-1}$ と見つるられる。

遅い変化のほ5は $\mathrm{SF}_{4}$ の加水分解過程に帰せられ た。 $\mathrm{SF}_{4}-9 \mathrm{H}_{2} \mathrm{O} \longrightarrow \mathrm{SO}_{3}^{2-}+4 \mathrm{~F}^{-}+6 \mathrm{H}_{3} \mathrm{O}^{+}$。その変化の 速さは中性で最も扰そく，酸性でる，アルカリ性でる 速くなり $k_{\Psi}=k_{0}+k_{a}\left[\mathrm{H}_{3} \mathrm{O}^{+}\right]+k_{b}[\mathrm{OH}]$ と表わされ る。 $\mathrm{pH}$ に独立な加水分解速度定数 $k_{0}$ は $9.5 \times 10^{3} \mathrm{sec}^{-1}$, 酸扣上びアルカリ触媒的同速度定数はそれぞれ， $k_{a}=$ $8.5 \times 10^{7}, k_{b}=7.0 \times 10^{9} M^{-1} \sec ^{-1}$ である。これらの加 水分解反応の律速段階はその単純な時間依存性から考 えて, $\mathrm{H}_{3} \mathrm{O}^{+}, \mathrm{OH}^{-}$または $\mathrm{H}_{2} \mathrm{O}$ の $\mathrm{SF}_{4}$ への最初の攻 撃であろう。

(藤田)
2615 pH 1. 3〜13 た おけ 酸素溶存ギ酸水 [3・2] 溶液の放射線分解および水の $\boldsymbol{\gamma}$ 線分解に おける一次生成物の収率

Radiolysis of $\mathrm{HCOOH}+\mathrm{O}_{2}$ at $\mathrm{pH} 1.3-13$ and the Yields of Primary Products in $\gamma$ Radiolysis of Water

I.G. Draganić, M.T. Nenadović, Z.D. Draganić: J. Phys. Chem., 73 (8) 2564 71 (1969)

酸素溶存(濃度は $1 \mathrm{~m} M$ ) のギ酸水溶液（濃度は 0.1

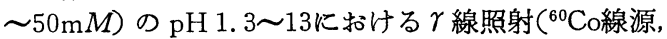
線量率 $5 \times 10^{17} \mathrm{eV} / \mathrm{ml} \cdot \mathrm{min}$, 線量は $2 \times 10^{17} \sim 1 \times 10^{18} \mathrm{eV} /$ $\mathrm{ml})$ を行なった場合の二酸化炭素 $\left(\mathrm{CO}_{2}\right)$, 水素 $\left(\mathrm{H}_{2}\right)$ および過酸化水素 $\left(\mathrm{H}_{2} \mathrm{O}_{2}\right)$ の $G$ 值を測定している。上 記濃度のギ酸溶液は, $\mathrm{pH}$ が 1.28 では $G\left(\mathrm{H}_{2}\right)$ は変化 しないが, $G\left(\mathrm{CO}_{2}\right)$ 㧊よび $G\left(\mathrm{H}_{2} \mathrm{O}_{2}\right)$ はいずれす濃度 とともに増加する。ギ酸濃度を一定(たと学ば $10 \mathrm{~m} M$ )
にして $\mathrm{pH}$ を1.3〜13とすると, $G\left(\mathrm{H}_{2} \mathrm{O}_{2}\right)$ だけが $\mathrm{pH}$ <3で増加する傾向がある。 $\mathrm{pH}$ 4. 4〜13 でギ酸濃度を 変化 (上記範囲) させた場合の各 $G$ 值は, その条件の もとでのギ酸イオン $\left(\mathrm{HCOO}^{-}\right)$の存在量にのみ依存し ていることをあげている。これらの実験結果を含めて 水の $\gamma$ 線分解の場合のヒドロキシルラジカル $(\mathrm{OH})$, 水和電子 $\left(e_{a q}^{-}\right)+$水素原子 $(\mathrm{H}), \mathrm{H}_{2}$ および $\mathrm{H}_{2} \mathrm{O}_{2}$ の一 次収率 $G \mathrm{OH}, G e_{a q}^{-}+G_{\mathrm{H}}, G_{\mathrm{H}_{2}}, G_{\mathrm{H}_{2} \mathrm{O}_{2}}$ を, つぎの関係 式, $G \mathrm{OH}=G\left(\mathrm{CO}_{2}\right), G_{\mathrm{H}_{2}}=G\left(\mathrm{H}_{2}\right), G e_{a q}^{-}+\mathrm{G}_{\mathrm{H}}=G\left(\mathrm{H}_{2}\right.$ $\left.\mathrm{O}_{2}\right)+G\left(\mathrm{H}_{2}\right)$ 打よび $2 \mathrm{G}_{2} \mathrm{O}_{2}=G\left(\mathrm{H}_{2} \mathrm{O}_{2}\right)+G\left(\mathrm{H}_{2}\right)-G$ $\left(\mathrm{CO}_{2}\right)$ を用いて計算している。 $G \mathrm{OH}, \mathrm{GH}_{2}, \mathrm{G}_{\mathrm{H}_{2} \mathrm{O}_{2}}$ およ び $G e_{a q}^{-}+G_{\mathrm{H}}$ の值は, $\mathrm{pH}$ 3 13 ではそれぞれ 2.72, $0.45,0.68$ 扎よび 3.18 ，また $\mathrm{pH} 1.3$ ではそれぞれ $2.85 ， 0.43 ， 0.76$ 打よ゙3.49 となっている。酸性度を 高めると水の分解量る増加することをあげている。

（浜島）
2616 パルス照射分解における水溶液中の $\mathbf{0}_{2}^{-}$[3・2] および $\mathrm{HO}_{2}$ の吸収スペクトルおよびそ の減衰の動力学

Absorption Spectrum and Decay Kinetics of $\mathrm{O}_{2}^{-}$and $\mathrm{HO}_{2}$ in Aqueous Solutions by Pulse Radiolysis, J. Rabani, S.O. Nielsen:

J. Phys. Chem., 73, (11) 3736 40 (1969)

過酸化水素 $\left(\mathrm{H}_{2} \mathrm{O}_{2}\right)$, 水素 $\left(\mathrm{H}_{2}\right)$ 打よび酸素 $\left(\mathrm{O}_{2}\right)$ の 混合ガスの水溶液に, 電子線のパルス照射（線源は直 線加速機，全線量は約 $1 \mathrm{Mrad}$ ）を行なった場合に生 成する O- ラジカルイオンの吸収スペクトル拉よびそ の減衰速度を測定している。亜酸化窒素 $\left(\mathrm{N}_{2} \mathrm{O}\right)$ を飽 和させ, $\mathrm{pH}$ が11.50拈よび12.98の $\mathrm{H}_{2} \mathrm{O}_{2}$ 溶液の照射 で生成した $\mathrm{O}_{2}^{-}$ラジカルイオンは, 240〜 $245 \mathrm{~mm}$ に 吸収極大 (吸光係数は $240 \mathrm{~mm}$ で $1,970 M^{-1} \mathrm{~cm}^{-1}$ ) があ り,このような条件のもとでは水和電子 $\left(e_{a q}^{-}\right)$と $\mathrm{N}_{2} \mathrm{O}$
との反応で $\mathrm{OH}$ ラジカルまたは O- ラジカルイオン が生成しこの両者のいずれかと $\mathrm{H}_{2} \mathrm{O}_{2}$ が反応して $\mathrm{O}_{2}^{-}$ を生成すると考えている。 $G\left(\mathrm{O}_{2}^{-}\right)$および $G\left(-\mathrm{H}_{2} \mathrm{O}_{2}\right)$ は, $\mathrm{pH} 11.5$ で5.6打よび5.5，また $\mathrm{pH} 13$ で5.8およ び5. 1 となるとしている。 $\mathrm{H}_{2}+\mathrm{O}_{2}$ 溶液の照射では $\mathrm{O}_{2}$ は $e_{a q}^{-}$扰よび水素原子 $(\mathrm{H})$ と反応して $\mathrm{HO}_{2}$ ラジカルの生成, また $\mathrm{OH}$ ラジカルと $\mathrm{H}_{2}$ との 反応で Hの生成が起こるとしている。 $\mathrm{O}_{2} 1 \mathrm{~atm}, \mathrm{H}_{2} 45$ atm の場合の生成物は $\mathrm{O}_{2}^{-}$および $\mathrm{HO}_{2}$ ラジカルで, この場合に $\mathrm{pH} 2$ では $\mathrm{HO}_{2}$ が解離して $\mathrm{O}_{2}^{-}$を生成する 可能性がなく, $G\left(\mathrm{HO}_{2}\right)$ は6.2 となること。 $\mathrm{HO}_{2}$ の $\mathrm{p} K$ $\left(K=\left[\mathrm{H}^{+}\right]\left[\mathrm{O}_{2}^{-}\right] /\left[\mathrm{HO}_{2}\right]\right)$ を 4.80, $\mathrm{HO}_{2}+\mathrm{HO}_{2}$ および $\mathrm{HO}_{2}+\mathrm{O}_{2}^{-}$の反応速度定数をそれぞれ $6.7 \times 10^{5}$ および $7.9 \times 10^{7} M^{-1} \mathrm{sec}^{-1}$ とした場合に, $\mathrm{O}_{2}^{-}$の減衰と $\mathrm{pH}$ の 関係の実測結果がよく説明できること，また $\mathrm{O}_{2}^{-}+\mathrm{O}_{2}^{-}$ の反応速度定数は $<10^{5} M^{-1} \mathrm{sec}^{-1}$ としている。（浜島） 
$2617 \mathbf{H}_{2}+\mathbf{O}_{2}$ 水溶液の ${ }^{60} \mathbf{C o}-\boldsymbol{\gamma}$ 線分解, $\mathbf{p H}$ が0. 46〜6.50における $G e_{a q}^{-}+G_{\mathrm{H}}$ の測定

The Cobalt-60 $\gamma$-Ray Radiolysis of Aqueous Solutions of $\mathrm{H}_{2}+\mathrm{O}_{2}$. Determination of $\mathrm{Ge}_{a q}^{-}+$ $G_{\mathrm{H}}$ at $\mathrm{pH} 0.46 \sim 6.5$

K. Sehested, H. Corfitzen, H. Fricke:

J. Phys. Chem., 74, (1) 211 13 (1970)

水素 $\left(\mathrm{H}_{2}\right)$ 打上び酸素 $\left(\mathrm{O}_{2}\right)$ の水溶液系の $\gamma$ 線照射 (線量率は $1 \mathrm{rad} / \mathrm{sec}$ 以下) で生成する $\mathrm{OH}$ ラジカルは $\mathrm{H}_{2}$ のみと反応, また生成する水和電子 $\left(e_{a q}^{-}\right)$拈よび 水素原子 $(\mathrm{H})$ はいずれも $\mathrm{O}_{2}$ のみと反応すると仮定し て過酸化水素 $\left(\mathrm{H}_{2} \mathrm{O}_{2}\right)$ の生成反応機構を考支てつぎの (a)式を導き，

$$
G e_{a q}^{-}+G_{\mathrm{H}}=G_{\mathrm{H}_{2} \mathrm{O}_{2}}-G_{\mathrm{H}_{2}}
$$

実測した $G_{\mathrm{H}_{2} \mathrm{O}_{2}}$ と $G_{\mathrm{H}_{2}}$ の文献值を用いて $G e_{a q}^{-a}+G_{\mathrm{H}}$ の值を求めている。この場合に $\mathrm{pH} 0.46 \sim 6.50$ (硫酸
表 $1 \quad G e_{\overline{a q}}^{-}+G_{\mathbf{H}}$ $\mathrm{pH}$ (a)式 (b)式

$6.50 \quad 3.21$

4. $25 \quad 3.21$

$2.74 \quad 3.25$

2.05

1.51

3.46

3. 26

3. 34

1.00

3. 47

3.57

3.67

0.46

$0.46^{*} \quad 3.67 \quad 3.67$

(*過塩素酸で $\mathrm{pH}$ 調

節し, $\mathrm{GH}_{2}$ は硫酸の値 を適用） 值は $\mathrm{pH} 0.46$ では硫酸溶液でも過塩素酸溶液でも同じ であった。 Res., 19, 636 (1963)

使用）の影響も調べている。 $\mathrm{pH} 6.5,0.15 \mathrm{mMO}_{2}+0.75$ $\mathrm{m} M \mathrm{H}_{2}$ 系では線量 $1 \mathrm{krad}$ ま で $\mathrm{H}_{2} \mathrm{O}_{2}$ の収量は線量に比例 して增加 し, $\mathrm{G}_{\mathrm{H}_{2} \mathrm{O}}=3.66$, $G_{\mathrm{H}_{2}}=0.45^{1)}$ なので表示の值 となる。また脱気した硫酸鉄 (II) 水溶液の $\gamma$ 線分解の測定 結果から(b)式を用い， $G e_{a q}^{-}+G_{\mathrm{H}}=0.5 G \mathrm{Fe}^{3+}-G_{\mathrm{H}_{2}}$

算出した値も同時に示されて いる。両値は $\pm 0.3 \%$ 以内で よく一致している。 $G \mathrm{Fe}^{3+}$ の 1) C.H.Cheek, et al., Radiation （浜島）

\section{8 ホスフィンとアンモニアの気相放射線} 化学の比較研究

A Comparative Study of the Gas-Phase Radiation Chemistry of Phosphine and Ammonia James W. Buchanan and Robert J. Hanrahan: Radiation Res., 42, 244〜54 (1970)

気相において純粋のホスフィン $\left(\mathrm{PH}_{3}\right)$ と純粋のア ンモニア $\left(\mathrm{NH}_{3}\right)$ に $\mathrm{Co}-60 \gamma$ 線を照射し, その分解機 構を比較研究した。線量率の測定は, エチレンの水素 生成の $G$ 值が1.2, $\mathrm{PH}_{3}$ および $\mathrm{NH}_{3}$ のエチレンに対 する電子阻止能がそれぞれ1.041拉よび0.661であると 仮定してェチレンの水素生成量を測定して決定した。 試料セルは, 最大の放射線強度を得るためにCo-60が はいるための陚験管型のくぼみ, cold finger 打よび breakseal を付けた $1 l$ の丸底フラスコを用いた。生
成物の分析にはガスクロマトグラフと質量分析計とを 用いた。両方とす分解してそれぞれその構成元素が生 成した。 $\mathrm{PH}_{3}$ の全反応は $\mathrm{PH}_{3} \rightarrow \mathrm{Pred}+3 / 2 \mathrm{H}_{2}$ である。 $0.4 \times 10^{20}$ から $5 \times 10^{20} \mathrm{eV}$ までの範囲の線量では水素生 成の $G$ 值は11.3であり，それ以上の線量では $G$ 值が減 少する。 50 ton から 1 気圧までは生成物の収率は $\mathrm{PH}_{3}$ の圧力に比例し，圧力零に補外すると収率は零であ る。 $\mathrm{NH}_{3}$ では, $1 \times 10^{20}$ から $5 \times 10^{20} \mathrm{eV}$ までの範囲の 線量では, 分解して生ずる窒素と水素との収率は線量 に比例し，そのG值はそれぞれ 1.5 おび4.5である。 全生成物の収率は線量零に補外すると零である。100 torr から 1 気圧までの範囲では $G$ 值は圧力に依存しな い。生成物の収率は圧力零に補外すると零になる。以 上の結果を説明する反応機構が提案されている。

（進藤）

\section{9 核酸構成分子と関連化合物のパルス放 射線分解。 I．5,6-ジヒドロチミニル遊 離基の光学吸収と反応性}

Pulse Radiolysis of Nucleic Acid Constituents and Related Compounds. I. Optical Spectrum and Reactivity of the 5,6-Dihydrothyminyl Free Radical

L.S. Myers, Jr., and L.M. Theard:

J. Am. Chem. Soc., 92, (9) 2868 70 (1970)

$\mathrm{N}_{2} \mathrm{O}$ を飽和した 5,6 -ジヒドロチミン (DHT) の希 薄水溶液に $\mathrm{pH} 6.8$ 扰よび1.0でパルス放射線を照射し た結果 $300 〜 600 \mathrm{~nm}$ の領域にわたる光学的吸収が観測 された。吸収は $400 \mathrm{~nm}$ に最大值を有し， 2 分子反応 で消滅しつつ, $800 \mu \mathrm{sec} に$ 至るまで見られた。プロト ネーションによると思われる両 $\mathrm{pH}$ 間の吸収極大のシ
フトはわずかである。

この水溶液系では吸収は $\mathrm{OH}$ ラジカルと DHT と の反応で生じたすのと考えられるが，他の条件ではH ラジカルと反応しても現われ, $e_{a q}^{-}$との反応からは観測 されない。この吸収は5,6-ジヒドロチミニルラジカル (多分5-yl ラジカル OC- $\mathrm{NH}-\mathrm{CH}_{2}-\mathrm{C}_{5}\left(\mathrm{CH}_{3}\right)-\mathrm{CO}-\mathrm{NH}$ ) と帰属された。分子内反応に関して䗆定で 2 分子反 忘で消滅し, $\mathrm{pH}=6.8,1.0 て ゙ ~ 2 k$ はそれぞれ $2.35 \times 10^{9}$, $1.3 \times 10^{9} M^{-1} \mathrm{sec}^{-1}$ である。酸性で遅くなるのはラジ カルのNの位置へのプロトネーションによるもので女 る。これらの実験結果は, チミンとH-ラジカルとの 反応で生ずるというラジカルの吸収に関する知見と一 致し，したがってチミンの場合には， H-ラジカルが 5〜6位間の二重結合に付加すること（多分，5位）は 確かであり，また水和電子の付加とそれに続くプロト ネーションによっては 5-yl, 6-yl のいずれのラジカ ルも生じないと考えられる。
（藤田） 
2620 核酸構成分子と関連化合物のパルス放 [3・3 射線分解 II . シトシン水溶液中の短寿 命吸収の解析

Pulse Radiolysis of Nucleic Acid Constituents and Related Compounds. II. Resolution of a Rapid Decaying Transient Absorption in Cytosine Solutions

L.S. Myers, Jr., A. Warnick, M.L. Hollis, J.D. Zimbrick, L.M. Theard and F.C. Peterson:

J. Am. Chem. Soc., 92, (9) 2871 4 (1970)

$\mathrm{N}_{2} \mathrm{O}$ 飽和シトシン 水溶液のパルス放射線照射で得 られる吸収は，pH 7 拈よび 12.3 でそれぞれ時間とと もに形の変わらない別々のスペクトルを示す。一方, pH11.4で得られる吸収は 330 打よび $450 \mathrm{~nm}$ 付近で, 一部, 約 $1 \mu \mathrm{sec}$ の半減期で減少し, 約 $4 \mu \mathrm{sec}$ 後に $\mathrm{pH} 12.3$ のスペクトルに近づく。減少した部分のスペ クトルはまた, $\mathrm{pH} 7$ のそれに類似しているよ5に思
われる。

pH11.4に打けるこれらの現象はパルス直後のスペ クトルが 2 つのラジカル $\mathrm{R}_{1}$ ・ と $\mathrm{R}_{2}$ ・のそれの合成さ れたすのであり，同時にきわめて速い速度で $\mathrm{R}_{1}$ ・が $\mathrm{R}_{2}$ ・ 飞変換していると考光ることができる。ここで $\mathrm{R}_{1}$ ・は 5 または 6 位に $\mathrm{OH}$ ラジカルが付加した中性 ラジカルであり, $\mathrm{R}_{2}$ ・は $\mathrm{R}_{1} \cdot$ と $\mathrm{OH}^{-}$が反応して生

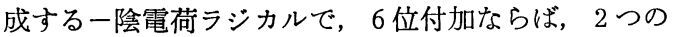
共役体を持つであろら。

$$
\begin{gathered}
\mathrm{O}=\mathrm{C}-\mathrm{NH}-\mathrm{CH}\left(\mathrm{O}^{-}\right)-\dot{\mathrm{C}} \mathrm{H}-\mathrm{C}\left(\mathrm{NH}_{2}\right)=\mathrm{N} \\
-\mathrm{O}-\mathrm{C}=\mathrm{N}-\mathrm{CH}(\mathrm{OH})-\dot{\mathrm{C}} \mathrm{H}-\mathrm{C}\left(\mathrm{NH}_{2}\right)=\mathrm{N}
\end{gathered}
$$

この考えに基ついて計算された $\mathrm{R}_{1}$ ・濃度の $\mathrm{pH} 10.8$ から11.7 亿打ける半減期加 $\mathrm{R}_{1}$. と $\mathrm{OH}^{-}$の 2 分子 反応速度定数は $3.5 \times 10^{8} M^{-1} \mathrm{sec}^{-1}, \mathrm{R}_{1}$ ・のイオン化の $\mathrm{pK}$ の上限值は 10.7 あ゙る。 $\mathrm{pH} 11.4$ に扰いてパルス と同時に $\mathrm{R}_{2}$ ，が生成するのは，シトシンとOーの反応 で直接できるためである。
2621 核酸構成分子と関連化合物のパルス放 [3・3] 射線分解。III.ピリミジン塩基と $\mathbf{O H}$ の 反応で生成する遊離基の光学的吸収と反 応性

Pulse Radiolysis of Nucleic Acid Constituents and Related Compounds. III. Optical Spectra and Reactivity of Organic Free Radicals Formed by Reaction of Hydroxyl Free Radicals with Pirimidine Bases

L.S. Myers, Jr., M.L. Hollis, L.M. Theard,

F.C. Peterson and A. Warnick:

J. Am. Chem. Soc., 92, (9) 2875 82 (1970)

ピリミジン塩基であるシトシン (C), メチルシトシ ン $(\mathrm{MC})$, ウラシル(U), チミン(T)等は $\mathrm{pH} 7$ の水溶 液中でそれぞれ 5 または 6 位の炭素に $\mathrm{OH}$ の付加した
同型の中性ラジカル $\mathrm{R}_{1}$ ・を与えるが ( 5 位と 6 位の割 合は不明), $\mathrm{pH}$ が高くなるにつれてそれぞれ異なった 挙動を示す。

この研究シリーズの II に打いてシトシンより生ずる $\mathrm{R}_{1}$ ・はより高い $\mathrm{pH}$ で $\mathrm{OH}^{-}$と反応して $\mathrm{R}_{2}$ ・なる一陰 電荷ラジカルになること示したが, ウラシルでは $\mathrm{pH}$ 11. 4で対応する $\mathrm{R}_{2}$ ・はさらに $\mathrm{OH}^{-}$と反応して $\mathrm{R}_{3}$ ・な る 2 院電荷ラジカルを生成する。これはまた U-十

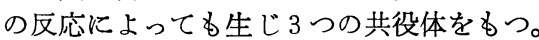

5 位の炭素にメチル基がついたチミンも $\mathrm{R}_{3}$ ・型の ジカルを与えるが， $\mathrm{T}^{-}+\mathrm{O}^{-}$の反応は遅く，この反応 からはむしろ $\mathrm{R}-\mathrm{CH}_{3}+\mathrm{O}^{-} \longrightarrow \mathrm{R}-\mathrm{CH}_{2} \cdot+\mathrm{OH}^{-}$のよ 5 にメチル基の位置のラジカルを与える。

この傾向はメチルシトシンに扔いてょり著しく, pH 12.6 に拈いて観測される吸収はほとんどすべて $\mathrm{R}-\mathrm{CH}_{2}$ ・型である。これは 4 位の置換基がアミノ基で あることによると思われる。

(藤田)

\section{2 低温ガラスでの電子捕捉 A. パルス [3・3] 放射線分解}

Trapping of Electrons in Low-Temperature Glasses. A. Pulse Radiolysis Study

J.T. Richards and J.K. Thomas:

J. Chem. Phys., 53, (1) 218 24 (1970)

3-メチルペンタン (3-MP), 2-メチルテトラヒドロ フラン (MTHF), クメン, エタノール $(\mathrm{EtOH})$, アル

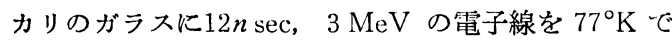
照射し，それらの捕捉電子 $\left(e_{\imath}^{-}\right)$の吸収を調べた。3$\mathrm{MP}, \mathrm{MTHF}, \mathrm{MeOH}$ では照射直後のスペクトルと4 $\mu \sec$ 後のそれとは異なり, $\mathrm{MeOH}$ の場合, 短寿命種 のものが観測された。それらは種々の系での異なった 深さのトラップに捕捉された電子に起因する。

一方, アルカリガラスではそのスペクトルは照射後
の時間による変化はない。電子捕捉の過程 と site の 種類の検討のために 3-MP で観測される中間体 $e_{\imath}^{-}$に およばすビフェニル，または四塩化炭素添加の影響が 調べられた。また正孔捕捉剤の影響も3-MPガラスに ついて調べた。2-MP-1 の添加はスペクトルにはとん ぞ影響しないが，MTHF の添加は長波長部分の吸収 を増加させる。1 $10^{-2} M$ のナフタレンを添加すると， $77^{\circ} \mathrm{K}$ では溶質のイオン (small yield) を生成し, $123^{\circ} \mathrm{K}$ に昇温与ると，ナフタレンの三重項 $(G=0.05)$ と一重項を与える。

(沈井) 
2623 照射した炭化水素および炭化水素のア $[3 \cdot 3]$ ルコール溶液中でのスカベンジャーとし てのヨウ素の作用

Studies on Iodine as a Scavenger in Irradiated Hydrocarbons and Hydrocarbon-Alcohol Solutions

R.H. Johnsen, N.T. Barker, M. Burgin:

J. Phys. Chem., 73, (10) 3204 8 (1969)

3 3ーメチルペンタン (MP), $n$-ヘキサン $(n \mathrm{H})$ 打よび シクロヘキサン $(\mathrm{cH})$, また $n \mathrm{H}-$ エタノール $(\mathrm{EtOH})$ 招よび $\mathrm{cH}-\mathrm{EtOH}$ にヨウ素 $\left(\mathrm{I}_{2}\right)$ を溶解した系に, 真 空中でX線照射（線源は $3-\mathrm{MeV}$ の Van de Graaff 加速機，吸収線量は約 $2 \times 10^{18} \mathrm{eV} / \mathrm{g}$ ) を行ない，生成 するヨウ素イオン $\left(\mathrm{I}_{3}^{-}\right)$の $G$ 值を $360 \mathrm{~nm}$ の吸光度から 求めている。 $G\left(\mathrm{I}_{3}^{-}\right)$は $\mathrm{I}_{2}$ 濃度とともに增加するが,
その最高值は $\mathrm{MP}-\mathrm{I}_{2}$ 系では1. $56, n \mathrm{H}-\mathrm{I}_{2}$ 系では 2.42, また $\mathrm{cH}-\mathrm{I}_{2}$ 系で 1.8 と 2.2の間（再現性が悪いため） としている。これらの值はそれぞれの系でのヨウ化水 素 $(\mathrm{HI})$ 扰よび水素原子の生成 $G$ 值とも比較的によく 一致すること, とくに $n \mathrm{H}-\mathrm{I}_{2}$ 系では電子 $\left(e^{-}\right)$の生成 $G$ 值とすよく一致することをあげている。 3 成分系の $G\left(\mathrm{I}_{3}^{-}\right)$は, $n \mathrm{H}-\mathrm{I}_{2}-\mathrm{EtOH}$ 系で, $\mathrm{I}_{2}$ 濃度が $1 \mathrm{~m} M$ では, $\mathrm{EtOH}$ 濃度が1.2M以上でほほ一定(2.4)となっている。 また $\mathrm{cH}-\mathrm{I}_{2}-\mathrm{EtOH}$ 系で, $\mathrm{I}_{2}$ 濃度が $1 \mathrm{~m} M$ では, $\mathrm{EtOH}$ 濃度が $1.1 M$ 以上でもその濃度とともに増加し，この 傾向は $\mathrm{cH}^{-} \mathrm{I}_{2}$ 系での $G(\mathrm{HI})$ とよく一致することを あげている。また各種のアルコールを共存させた系で の溶媒和電子の生成 $G$ 值などの報告結果などを考虑し $\tau, \mathrm{I}_{2}$ は選択的に $e^{-}$と反応し, $G\left(\mathrm{I}_{3}^{-}\right)=G\left(e^{-}\right)$とな ることなどを示唆している。

（浜島）
2624 三フッ化ヨウ化メタンの気相における [3・3〕 放射線分解

The Radiolysis of Trifluoroiodomethane in the Gas Phase

I. McAlpine, H. Sutcliffe:

J. Phys. Chem., 73, (10) 3215 18 (1969)

三フッ化ヨウ化メタン $\left(\mathrm{CF}_{3} \mathrm{I}\right)$ ガス 2.2 lをパイレッ クスガラス球に 1 気圧につめ， $\gamma$ 線照射 (線源は ${ }^{60} \mathrm{Co}$, 線量率は約 $0.73 \mathrm{Mrad} / \mathrm{hr}$ ) を行ない, 生成物は真空中 でトラップの温度をー23，-63，-131およびー $196^{\circ} \mathrm{C}$ にして分別凝縮を行なっている。各成分はその分子量, 赤外吸収スペクトルの测定打よびガスクロマトグラフ 分析でそれぞれ確認している。各温度で疑縮するすの は, $-23^{\circ} \mathrm{C}$ 区分はヨウ素 $\left(\mathrm{I}_{2}\right),-63^{\circ} \mathrm{C}$ 区分は二フッ化 二ヨウ化メタン $\left(\mathrm{CF}_{2} \mathrm{I}_{2}\right),-131^{\circ} \mathrm{C}$ 区分は未反応の $\mathrm{CF}_{3} \mathrm{I}$,

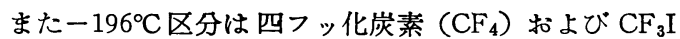
である。吸収線量が $(1.185 \sim 44.47) \times 10^{21} \mathrm{eV}$ での生 成物は $\mathrm{I}_{2}, \mathrm{CF}_{2} \mathrm{I}_{2}$ および $\mathrm{CF}_{4}$ で, 各生成物の収量は吸 收線量に此例して增加して括り, それぞれの生成 $G$ 值 は0.13，1.08打よび0.82となっている。現在のところ 三フッ化炭素ラジカルがフッ素を引抜く反応を起こす ことが知られていないこと，放射線分解で生成した同 ラジカルは光分解扣よび熱分解で生成したラジカルよ りも反応性が大きいであろうこと，生成物中に六フッ 化エタン $\left(\mathrm{C}_{2} \mathrm{~F}_{6}\right)$ が存在しないこと, 生成物中の炭素原 子とフッ素原子の存在比は $1: 3.2$ となっているなどの 結果から, 器壁からのフッ素の引抜き反応が起こって いると考劣ている。また酸素を共存させた場合に生成 する六フッ化ジメチルエーテル扰よびフッ化カルボニ ルの生成機構を推定している。

（浜島）
2625 アルコール水溶液のパルス照射分解に [3・3]

\section{関する研究}

Pulse Radiolysis Study of Alcohols in Aqueous

Solution

M.Simic, P.Neta, E. Hayon:

J. Phys. Chem., 73, (11) 3794 800 (1969)

メタノール $(\mathrm{MeOH})$, エタノール $(\mathrm{EtOH})$, イン プロパノール $(i-\mathrm{PrOH})$, ノルマルー $(n-)$, イソー (i-) 拉よび第三 $(t-)$ ブタノール $(\mathrm{BuOH})$, ネオぺ ンタノール $(\mathrm{NpOH})$ およびシクロヘキサノール $(c-$ $\mathrm{HxOH}$ ) の水溶液に電子線パルス照射（線源は Febetron-705，2.3-MeV のパルス持続時間は約 $30 n \mathrm{sec}$

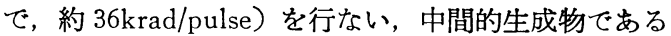
ヒドロキシアルキルラジカル $(\cdot \mathrm{ROH})$ 扰よびラジカ ルアニオン $\left(\cdot \mathrm{RO}^{-}\right)$のスペクトルの吸収極大 $\left(\lambda_{\max }\right)$,
減数定数拈よび $\mathrm{p} K$ 值を求めている。ほとんどの実験 は亜酸化窒素を $1 \mathrm{~atm}$. で飽和させているので水和電 子の約 $98 \%$ OH ラジカルに変換されているとして いる。中間的生成物による $\lambda_{\max }$ は, $\mathrm{MeOH}$ および $\mathrm{EtOH}$ では $210 \mathrm{~nm}$ までに認められなく, 中性の $i$ $\mathrm{PrOH} 214 \mathrm{~nm}, n-\mathrm{BuOH} 222 \mathrm{~nm}, i-\mathrm{BuOH} 225 \mathrm{~nm}$, $t-\mathrm{BuOH} 225 \mathrm{~nm}, \mathrm{NpOH} 238 \mathrm{~nm}$, および $c-\mathrm{HxOH}$ $230 \mathrm{~nm}$ となっている。中性での酸素飽和 $\mathrm{MeOH}, i$ $\mathrm{PrOH}, c-\mathrm{HxOH}$ および $t-\mathrm{BuOH}$ 溶液ではすべて $\lambda_{\max }$ は240〜250nm にあり, 酸性とアルカリ性では $\lambda_{\max }$ に変化はないが $t-\mathrm{BuOH}$ を除いてその吸光係 数に差（アルカリ性で大）があることをあげている。 これらの結果などから・ROH 拈よび・ROーラジカル などの中間的生成物の減衰する反応の機構を推定して いる。 
$2626 \gamma$ 線照射による炭化水素結晶中のフリ ーラジカル生成。アルキルラジカルの ESR スベクトル

Free Radical Formation in Hydrocarbon Crystals by $\gamma$-Irradiation. Electron Spin Resonance Spectra of Some Alkyl Radicals

T. Gillbro, P.-O. Kinell, A. Lund:

J. Phys. Chem., 73, (12) 4167 74 (1969)

直鎖状アルカン (ペンタン, $\mathrm{C}_{5}$; ヘキサン, $\mathrm{C}_{6}$; ヘ プタン, $\mathrm{C}_{7} ;$ ノナン, $\mathrm{C}_{9} ;$ デカン, $\mathrm{C}_{10}$; ウンデカン,


は ${ }^{60} \mathrm{Co}$, 線量率は $0.18 \mathrm{Mrad} / \mathrm{hr}$, 線量は打子に 3 Mrad）を行ない，その X-帯拈上びQ-带の ESR ス ペクトルを測定し， 4 重線， 3 重線拈よび 2 重線のカ ップリング定数 $\left(a_{1}, a_{2}, a_{3}\right)$ を求めている。単結晶を 照射した場合は， $\mathrm{C}_{6}$ では $\theta^{\prime}=0^{\circ}\left(\theta^{\prime}\right.$ は試料の回転軸 が垂直軸となす角度）のときに $a_{1}=25.9 G, a_{2}=33.6$
$G, a_{3}=33.2 G$, また $\theta^{\prime}=90^{\circ}$ では $a_{1}=23.8 G, a_{2}=$ 34. $3 G, a_{3}=12.5 G, \mathrm{C}_{9}$ では $\theta^{\prime}=0^{\circ}$ で $a_{1}=25.5 G, a_{2}$ $=a_{3}=33.5 G, \mathrm{C}_{10}$ では $\theta^{\prime}=0^{\circ}$ で $a_{1}=25.6 G, a_{2}=a_{3}$ $=33.3 G, \theta^{\prime}=90^{\circ}$ で $a_{1}=23.7 G, a_{2}=34.2 G, a_{3}=13.2$ $G, \mathrm{C}_{11}$ はスペクトルの分解能が低く解析していない。 多晶体を照射した場合の $\mathrm{C}_{5} \sim \mathrm{C}_{11}$ のスペクトル変化は きわめてゆるやかで，Q-帯のスペクトルは非対称性 が著しい。 $a_{1}=25 \pm 1 G, a_{2}=33 \pm 1 G, a_{3}=12.5 \sim 33 G$ から, $\mathrm{CH}_{3}-\dot{\mathrm{C}} \mathrm{H}-\mathrm{CH}_{2}-\mathrm{R}$ の構造をるつラジカルが存在 すること，またこのラジカルは 2 番目の炭素に結合し ている水素の引き抜きで生成与るとしている。 $\mathrm{C}_{7} \sim$ $\mathrm{C}_{11}$ からは上記以外の構造をもつラジカルの存在を認 わている。またラジカルは C-C 結合の切断によって は生成しがたいことをあげている。

（浜島）

\section{7 放射線照射によるシクロヘキサン中の}

$[3 \cdot 3]$

\section{スチルベンの異性化に対する電荷捕捉剤 の影響}

The Effect of Charge Scavengers on RadiationInduced Isomerization of Stilbene in Cyclohexane

R.R. Hentz, H.P. Lehmann:

J. Phys. Chem., 73, (12) 4283 89 (1969)

スチルベン $(\mathrm{St})$ のシクロヘキサン溶液に $\gamma$ 線照射 （線源は $4-\mathrm{kCi}$ の ${ }^{60} \mathrm{Co}$, 線量率は $1.51 \times 10^{18} \mathrm{eV} / \mathrm{ml}$.

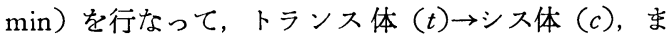
た $c \rightarrow t$ への異性化に及ぼす電子スカベンジャ一（酢 酸ベンジル, ニトロベンゼソ, 塩化メチル, $\mathrm{N}_{2} \mathrm{O}, \mathrm{CO}_{2}$ など）扰よびカチオンスカベンジャ一（ピペリジン， $\mathrm{NH}_{3}$ など) の影響を調べている。 $t$-St での $t \rightarrow c$ の

\section{8 放射線照射による有機分子の酸化およ び還元に対す磁気共鳴研究}

Magnetic Resonance Studies of the Oxidation and Reduction of Organic Molecules by Ionizing Radiation

H.C. Box, H.G. Freund, K.T.Lilga, F.E. Budzinski:

J. Phys. Chem., 74, (1) 40 52 (1970)

$4.2{ }^{\circ} \mathrm{K}$ にてチ才尿素誘導体（モノメチルー扣よびジ ブチルチオ尿素), 二硫化物(ベンゾイルジスルフィド, ジチオジグリコール酸, シスチンハロゲノ酸塩), 一 硫化物 (チオジグリコール酸), ジカルボン酸(コハク 酸, ジメチルマロン酸), グリシンおよびその塩酸塩 の単結晶に $\mathrm{X}$ 線 $(250-\mathrm{kV}, 30-\mathrm{mA}$ で10 min) 照射を 行なった試料の ESR スペクトル，ある場合には電子一 核二重共鳴（endor）スペクトルの結晶軸と磁界の関
$G$ 值, $G(c \rightarrow t)$ と $t-\mathrm{St}$ の初濃度 $\left(S_{1}\right)$, スカンベンジ 七一濃度 $\left(S_{2}\right)\left(\alpha_{2}\right.$ はスカベンジャ一による定数) との 関係式は, $G(c \rightarrow t)=0.50\left\{3.9 \sqrt{16 S_{1}+\alpha_{2} S_{2}} /(1+\sqrt{16}\right.$ $\left.\overline{\left.S_{1}+\alpha_{2} S_{2}\right)}\right\} \times 16 S_{1} /\left(16 S_{1}+\alpha_{2} S_{2}\right)$ で表わせ, $S_{2}=0$ の 場合は $S_{1}=0.1 M$ で $G$ 值は 1.16 となり, とくに $S_{1}>$ $0.03 M$ でよく一致する。また $S_{1}$ が0.01拈よび0.1の 場合は, $\mathrm{CO}_{2}$ の濃度によって $G$ 值は変化しない $\left(\alpha_{2}=\right.$ 0) が，これは $\mathrm{CO}_{2}^{-}$と $\mathrm{St}^{+}$とが反応して St 励起分 子を生成するためと考えている。 $\alpha_{2}$ の值は種々のス カベンジャ一に対して求められている。 $c$-St での $G$ $(c \rightarrow t)$ は $c-\mathrm{St}$ 濃度が 0.1 扣よび $0.2 M$ の場合にそれ ぞれ4.6扰よび7.4となり，したがって0.1M 溶液では $G(c \rightarrow t) / G(t \rightarrow c) \fallingdotseq 4$ となっている。 $c \rightarrow t$ の異性化は 臭化エチル， $\mathrm{SF}_{6}$ の添加によって著しく促進される。 この場合の $G$ 值は再現性が悪く，この反応の詳細な機 構は推定するすべがないが，イオン反応が触媒的作用 の一役を果たしているすのと推定している。（浜島）
係を測定している。このような低温では，X線照射に よる酸化生成物 (OP) および還元生成物 (RP) が比 較的に安定であることをあげている。 ESR スペクト ルから OP 扎よび RP の構造を推定している。メチル チオ尿素では RP として 1 種類の㓌イオンと OP とし て 2 種類の陽インの存在, $30^{\circ} \mathrm{K}$ に加温しただけで, 不安定な陽イオンはより安定なるのに転化すること, またこの陽イオンのスピン密度は S 原子に局在してい ることなどを明らかにしている。二硫化物では RP と して -(S-S)-一, また OP として - (S-S)+ータイプの イオンの存在, ジカルボン酸では RP としていずれも $\mathrm{HO}-\mathrm{C}-\mathrm{O}-$ タイプの陰イオン, OP として O- $\mathrm{C}-\mathrm{O}(コ$

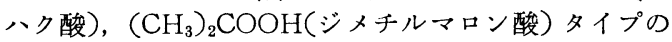
ラジカルの存在, グリシン塩酸塩では RPとして HO亭- $\mathrm{O}^{-}$タイプの陰イオン, OP として塩素分子イオン $\left(\mathrm{Cl}_{2}^{-}\right)$の存在を考えている。これらの生成 $G$ 值も求め られている。
(浜島) 
2629 液相シクロヘキサンの放射線分解にお ける原子状および分子状水素の収率に及 ほす電子, 陽イオンおよび水素原子スカ ベンジャーの影響

The Effect of Electron, Positive Ion, and Hydrogen Atom Scavengers on the Yields of Atomic and Molecular Hydrogen in the Radiolysis of Liquid Cyclohexane

K. D. Asmus, J.M. Warman, R.H. Schuler:

J. Phys. Chem., 74, (2) 246 57 (1970)

シクロヘキサンに 11 種類のスカベンジャー $\left(\mathrm{N}_{2} \mathrm{O}\right.$,

$\mathrm{SF}_{6}, \mathrm{CO}_{2}, \mathrm{CH}_{3} \mathrm{Cl}, \mathrm{CH}_{3} \mathrm{Br}, \mathrm{C}_{2} \mathrm{H}_{5} \mathrm{Br}, \mathrm{C}_{2} \mathrm{H}_{4}, \mathrm{C}_{2} \mathrm{D}_{4}, c-\mathrm{C}_{3} \mathrm{H}_{6}$, $c-\mathrm{C}_{3} \mathrm{D}_{6}, \mathrm{ND}_{3}$ ) を添加した系に真空中, 室温で $\gamma$ 線照 射を行ない $\left({ }^{60} \mathrm{Co}, 6 \times 10^{18} \mathrm{eV} / \mathrm{g} \cdot \mathrm{hr}\right.$, 最高 $2 \times 10^{19} \mathrm{eV} /$ $\mathrm{g})$, 水素 $\left(\mathrm{H}_{2}\right)$ の生成 $G$ 值に及ぼす影響を調べている。 純シクロヘキサンからの照射線量の影響を補正した $\mathrm{H}_{2}$ の $G$ 值, $G\left(\mathrm{H}_{2}\right)_{0}=5.67$ としいる。電子スカペン
ジャー(ハロゲンアルキル, $\mathrm{N}_{2} \mathrm{O}, \mathrm{SF}_{6}, \mathrm{CO}_{2}$ ) の添加

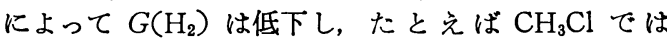
$G\left(\mathrm{H}_{2}\right)_{0}-G\left(\mathrm{H}_{2}\right)$ はメチルラジカルの生成 $G$ 值とほぼ等 しい。陽イオンスカベンジャ一 $\left(\mathrm{ND}_{3}\right.$, シクロプロパ ン）の添加によって $G\left(\mathrm{H}_{2}\right)$ は低下し，たとえば0.102 $M$ の $c-\mathrm{C}_{3} \mathrm{D}_{6}$ の添加で全水素の $G$ 值は 4.99 となり, その 万ち $G\left(\mathrm{H}_{2}\right)$ は 4.96 となっている。エチレンは陽 イオンおよび水素原子 $(\mathrm{H})$ のスカベンジャーとして作 用するのでェチルラジカルの $G$ 值から簡単には $G(\mathrm{H})$ を求められないことなどをあげている。以上の諸結 果，その他の結果を検討し，純シクロヘキサンの放射 線分解による $G\left(\mathrm{H}_{2}\right)$ の生成経路をつぎのように推定 反応経路 分子状 原子状している（分子状の $G$ イオン性 $3.01 \quad 0.89 \quad\left(\mathrm{H}_{2}\right)=4.21$, 原子状の 非イオン性 $\left.1.20 \quad 0.57 \quad G\left(\mathrm{H}_{2}\right)=1.46\right) 。$

(浜島)
2630 高電場でのネオペンタンの放射線誘起 [3・3] 電気伝尔度とイオン収率

Radiation-Induced Conductivity and Ion Yield in Neopentane at High Electric Fields

Werner F. Schmidt:

Radiation Res., 42, 73〜78 (1970)

液体ネオペンタンに $140 \mathrm{kV} / \mathrm{cm}$ 以上の電圧を印加し て, その電圧対イオン電流を求め, 自由イオンの $G$ 值 およびイオン対をつくるために必要なエネルギーWを 計算した。

${ }^{60} \mathrm{Co}-\gamma$ 線で0. 125〜8.1 mrad/sec の範囲まで照射し ながら種々の電圧のもとで測定した。そのときの電極 には $20 \mathrm{~mm} \psi$ の円板の $\mathrm{Al}$ を使い, 電極間距離は 1.08 $\mathrm{mm}$ とした。測定用セルは $350^{\circ} \mathrm{C}$ に加熱し，10-6 Torr まで真空にした。サンプルは真空中でシリカゲルおよ
びNaK合金上を通してからセルに入れ $10 \mathrm{kV} / \mathrm{cm}$ の電

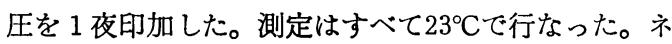
オペンタンのイオン化電流対電圧の関係はノルマルヘ キサンの場合と違って直線的にはならない。140kV/ $\mathrm{cm}$ の電圧の印加では $G=3.4$ であるが, Jaffe の式 ${ }^{1)}$ を使い, $1 / I$ 対 $1 / E$ のプロットで電場を無限大に補外 して求めると， $G=4.03$ となる。また Zahnstra の計 算式 ${ }^{2}$ から求めると $W=24.8 \mathrm{eV}$ となる。このG值お よびW值を他のアルカン類の場合と比較して電場下の 液体ネオペンタン中での照射によって生ずるイオン対 の状態が考察してある。

1) Ann. Phys., 42,303 44 (1913)

2) Physica, 2, 817 24 (1935)

（飴谷）

\section{1 連続方式によるスチレンの放射線溶液 [3・4] 重合}

Radiation-Induced Solution Polymerization of Styrene in an Engineering Flow System F.T. Osborne, S. Dmi, V.Stannett, and F.P. Stahel:

J. Phys., Sci., A-1, 8, (7) 1657〜74 (1970) イチレンクロリド中でのスチレンの放射線溶液重合 を連続式反态器を使用した小規模のパイロットプラン トで扣こなった。反応装置は総容積 $6 l$ で, ${ }^{60} \mathrm{Co}-\gamma$ 線 源間を通る管形反応器とかくはん槽とからなり，モノ マー溶液を循環できるようになっている。反応器には 温度調節ができるように冷却管が付設してある。この 装置で連続的に反応をおこならときの場所による線量 率の差は $8 \%$ 程度である。モノマー溶液は十分乾燥し
たのち，かくはん槽から反応器に送り循環させた。流 速をかえて線量率を変化させ, 種々の温度下に反応さ せ, 一定回数循環後反応物をとり出して種々の測定を おこなった。この結果1)モノマー溶液の乾燥により重 合速度が増加，2)重合速度は反応温度を下げることに より増加，3)平均分子量は反応温度が下がるにしたが って徐々に増加することが判明した。この状態での反 态はイオン重合とラジカル重合とが共存して扣り，30 ${ }^{\circ} \mathrm{C}$ でのラジカルによる反応速度は $1.01 \mathrm{~mole} / l \cdot \mathrm{sec}, 1$ オンによる反応速度は $3.91 \mathrm{~mole} / l \cdot \mathrm{sec},-11 \sim+30^{\circ} \mathrm{C}$ でのイオン重合の活性化エネルギーはー $1.9 \mathrm{kcal} / \mathrm{mole}$ と計算された。種々の検討の結果, この装置を $100 l$ 以上の規模に拡大できる可能性は十分あることがわか った。

（清水） 


\section{2 塗料塗膜の除染性についての研究}

Untersuchungen zur Dekontaminierbarkeit von Anstrichen

W. Berger, H. Hepp, P.F. Sauermann:

Farbe und Lack, 76, (1) 44〜9 (1970)

種々のバインダ一から成る 18 種の塗膜执よび 4 種の ライニング材について，放射性物質による污染に対す る除染性に関する試験を行なった。各試料は，あらか じめ, 数種の薬品, すなわち酸, アルカリ拉よび有機 溶剂類に対する抵抗性を試験しておいた。

污染，除染試験は，相互に関係のない2つの条件で 行なった。すなわち, 污染液として ${ }^{90} \mathrm{Sr}-{ }^{90} \mathrm{Y},{ }^{106} \mathrm{Ru}$ ${ }^{106} \mathrm{Rh},{ }^{137} \mathrm{Cs}$ および ${ }^{60} \mathrm{Co}$ の 4 種のラジオアイソトープ の塩酸溶液 $(10 \mu \mathrm{Ci} / \mathrm{ml}, \mathrm{pH} 4)$ およびウラン核分裂生 成物の硝酸溶液 $(10.9 \mu \mathrm{Ci} / \mathrm{ml}, \mathrm{pH} 1)$ の 2 通りのもの
を用いた。前者の場合には, 蒸留水, $1 N$ 塩酸扣よび 除染用ペーストを用いて 5 段階の除染を行ない, 後者 の場合には, 蒸留水, アルカリ性洗剂液および $5 \%$ 硝 酸を用いて 4段階の除染を行なった。除染の各段階ご とに残留放射能を測定し, 除染前と比較した。測定結 果の再現性はあまり良いものではなかった。

最も良い結果が得られたのは，ケイ素樹脂塗料， 2 成分型ポリウレタン塗料执よびライニング材, 塩化ゴ ム塗料ならびに環状化ゴム塗料であった。

（大段）

\section{3 分散型塗料中のメチルセルロースの挙 [4・1] 動の放射化学的研究}

Radiochemische Untersuchungen über das Verhalten von Methylcellulosen in Dispersionsfarben

W. Hansi, O.E. Christ, W. Schminke:

Farbe und Lack, 76, (1) 50 3 (1970)

${ }^{14} \mathrm{C}$ で標識したメチルセルロース（MC）を配合した 屋外用としてのポリ酢酸ビニルエマルション塗料の塗 膜について，一定の条件のもとでばく露試験を行なっ た。この実験によって，雨水により，MC がどの程度 まで塗膜から洗い去られるかが明らかになった。

約 3 か月の間に MC のおよそ $1 / 3 か ゙$ 塗膜から失われ た。とくに，ばく露の初期での失われ方が著しく，た とえば, 塗膜面積 $0.5 \mathrm{~m}^{2}$ あたりの $1.9 l$ 雨水で洗われた
ときの塗膜における放射能低下の割合は, 約50 $l$ で洗 った実験終期までの放射能低下の程度と比較して約 88 \%に達していた。また, 塗膜の表面近くの層からの $\mathrm{MC}$ の失われ方がとくに著しく, 全体の膜厚 $165 \mu$ の うち，表面に近い約 $10 \mu$ の層からは $\mathrm{MC}$ がほとんど 完全に失われ，その下の約 $35 \mu$ の層の間で急激に変化 し，それよりも下層では変化が少なくて約 $80 \%$ が残留 していた。

測定には, 捕集された雨水と, ばく露後の塗膜また はこれから表面層を順次けずり取ったものについて, 液体シンチレーションカウンターまたはメタンガスを 用いたフローカウンターによって行なわれた。

(大段)
2634 メタクリル酸エステル系ポリマー中の［4・2] 側鎖エステル基の加水分解のトレーサー による研究

A Tracer Study of the Hydrolysis of the Pendant Ester Groups in Polymers and Co-Polymers of Methacrylates

J.C. Bevington, R.Brinson, B.J. Hunt:

Makromol. Chem., 134, 327〜30 (1970)

メタクリル酸ベンジル (BMA), メタクリル酸エチ ル (EMA) 拉よびこれらのモノマーのアクリル酸メチ ル (MA) とのコポリマーならびにメタクリル酸メチ ル (MMA) と BMA とのコポリマーについて, それ らの側鎖エステル基のアルカリ加水分解に関する反応 性を, ${ }^{14} \mathrm{C}$ を用いて研究した。

EMA とコポリマーになっている場合の MA の加水
分解は 24 時間以内に完了するが, BMA とコポリマー になっている場合にはおそい。

MA に隣接するメタクリル酸エステルの加水分解は はなはだ容易である。

ホモポリマーの場合と比較してみると，MMA は BMA によって保護されており，また，BMA はMMA によって加水分解に対する感受性を増大させられてい ることがわかる。

MA を含むメタクリル酸エステルのコポリマーで は, 加水分解の最初の段階に打いて，モノマ一単位の 連続の長さが関係していると言える。また，それから 先の段階にまで反応は進むが，不均一系となるため に, 再現性のよい実験結果を得るのが困難であること がわかった。

(大段) 


\section{5 荷電粒子放射化分析法によるごく微量 [5・1]} 酸素, 炭素の定量

Ultra-Trace Determination of Oxygen and Carbon by Charged Particle Activation Analysis I.L. Rook, E.A. Schweikert:

Anal. Chem., 41, (7) 958〜63 (1969)

エネルギー等価厚さ法で微量の酸素, 炭素を定最与 るさい考慮すべき点を検封した。

$\left[I^{16} \mathrm{O}(\alpha, p n)^{18} \mathrm{~F}\right.$ による方法： $40 \mathrm{MeV} \alpha$ 線を雲母 $\left[\mathrm{KH}_{2} \mathrm{Al}_{3}\left(\mathrm{SiO}_{4}\right)_{3}\right]$, マイラー $\left(-\mathrm{OCH}_{2} \mathrm{CH}_{2} \mathrm{OOC}\right.$ 》 -CO- ${ }_{n}$ に照射した場合の放射化率ーエネルギー厚さ で可変する）曲線は一致したが，アルミニウム（酸素 を含む)に照射した場合の同曲線は ${ }^{27} \mathrm{Al}(\alpha, x){ }^{18} \mathrm{~F}$ の破 砕反応のしきい值 $32 \mathrm{MeV}$ 以上で著しく雲母, マイラー の曲線からはずれる。1 原子あたりでは ${ }^{27} \mathrm{Al}(\alpha, x)^{18} \mathrm{~F}$ 反応の起こる確率は ${ }^{16} \mathrm{O}(\alpha, p n)^{18} \mathrm{~F}$ 反応の起こる確率
の 1/100 であるが， マトリックス成分は不純物成分に 比しきわめて多量存在するので, 照射 $\alpha$ 線エネルギー に注意を要する。

$[\mathrm{II}]^{16} \mathrm{O}(p, \alpha)^{13} \mathrm{~N}$ による方法 : $20 \mathrm{MeV}$ の陽子線を 雲母, マイラーに照射して放射化率ーエネルギー(厚み) 曲線は大略一致したが, $8 \mathrm{MeV}$ 以下で ${ }^{13} \mathrm{C}(p, n)^{13} \mathrm{~N}$ と ${ }^{12} \mathrm{C}(p, \gamma)^{13} \mathrm{~N}$ 反応が起こるため多少のずれが認め られる。後者の 1 原子あたりの放射化率は前者の $5 \%$ 以下であるので ${ }^{3} \mathrm{He}$ 放射化法より良い分析法となり う。

[III ${ }^{12} \mathrm{C}(\alpha, \alpha n){ }^{11} \mathrm{C}$ による方法 : $40 \mathrm{MeV}$ 以上の $\alpha$ 線 エネルギーで照射しなければ感度がよくない。

$[\mathrm{IV}]^{12} \mathrm{C}(d, n)^{13} \mathrm{~N}$ による方法 : $20 \mathrm{MeV}$ の重陽子線 を用いた ${ }^{12} \mathrm{C}(d, n){ }^{13} \mathrm{~N}$ 法は ${ }^{12} \mathrm{C}\left({ }^{3} \mathrm{He},{ }^{4} \mathrm{He}\right){ }^{13} \mathrm{~N}$ 法に匹 敵する感度をるっている。

〔I]の結果から, シリコン試料に $40 \mathrm{MeV} \alpha$ 線を厚 さ10 $\mu$ のマイカ 6 枚を通過させたのち（約 $34 \mathrm{MeV}$ と なっている） 30 分照射し, ${ }^{16} \mathrm{O}$ から生成した ${ }^{18} \mathrm{~F}$ の陽 電子消滅 $\gamma$ 線を同時計数して試料中数 $\mathrm{ppm}$ の酸素を定 量したが赤外吸収法の結果と良く一致した。（氏平）

\section{6 生体内の放射能測定に対する胸部ファ [6・1] ントムの計画}

A Projection Chest Phantom for in vivo Dosimetry

D.A. Waite, B. V. Andersen, P.E. Bramson:

Amer. Ind. Hyg. Ass. J., May-June, 322 6 (1970)

原子力施設で超ウラン元素を取り扱う場合は, 最も 厳重に格納された状態で作業が実施されるが，これら 格納器は破損し, 放射線作業者がプルトニウム, アメ リシウム，キュリウムを拉びたェアロゾルにさらされ ることが考えられる。しかしこれらェアロゾルは一般 に酸化物として存在するため, 体液にはほとんど溶解 することなく，胃腸を通って排泄されるか，肺にたま る。肺中にたまったるののもっとも直接的な方法は生

\section{体肺の線量測定である。}

この直接測定を行なうにあたって，たいへん安い材 料で作られる，胸部ファントムが計画された。このフ アントムでは胸の厚さの変更や骨と等価な材料ででき た骨格構造の結合を有効に行ないえた。このファント ムは, ドープ塗料で処理した人造の肺をもち，どのよ うな肺吸着にも類似させることができる。設計では, $10 \sim 100 \mathrm{keV}$ の低エネルギーX線や $\gamma$ 線の测定を行な うような生体肺測定用カウンターの校正が行なえるよ らにされた。

ここでは市販のファントムを使用した結果との比較 や,ファントム構造の詳細について示され, このファ ントムの有用性が示された。

（加藤）
2637 12回シンチレーションと半導体検出器 [6・4] のシンポジウム

1970 12th Scintillation and Semiconductor Counter Symposium

IEEE Trans. Nucl. Sci., NS-17, (3) $1 \sim 494$ (1970)

1970年 3 月 11 日〜13 日にかけて Washington で開 らかれた第12回シンチレーション・半導体検出器シン ポジウムに提出された論文のうち, 放射線検出器の現 状を正確に反映し，かつ将来にむかって技術的な貢献 を与えうるような論文を選び，さらに口頭発表のみの ものでとくに重要な内容のものをつけ加えて論文集に まとめたすのである。

この論文集はつぎの 5 つの部門に分けられている。 すなわち高エネルギー検出器(11篇), 光電子増倍管と
シンチレーター( 8 篇), 半導体検出器とその応用 (21 篇), 映像その他による検出法 (11篇), 回路とシステ 么 ( 9 篇)。

半導体検出器としては $\mathrm{Ge}(\mathrm{Li})$ に関するものが過半 数を占め, $\mathrm{Si}(\mathrm{Li})$ の生物学医学への応用など Si に関 するもの数篇, CdTe に関するもの 3 篇が含まれてい る。高エネルギースペクトロメータ用に TlCl(I) 結晶 を用いた研究や, 速応性の光電子増倍管の開発研究, 半導体検出器によるスペクトルの自動処理方法に関す る総説などが注目される。

(佐藤) 


\section{RI 農学・生物学利用文献抄録集（64）}

\section{3 殺菌剂 Kitazin の作用機作}

Studies on the Mode of Action of Organophosphorus Fungicide, Kitazin Part II. Accumulation of an Amino Sugar Derivative on Kitazin-treated Mycelia of Pyricularia oryzae

T. Maeda, H. Abe, K. Kakiki, T. Misato: Kumini Chem. Ind. Co., Ltd., Ohte-machi, Chiyoda-ku, Tokyo, Agr. Biol. Chem., 34, (5) 700 9 (1970)

Kitazin (O, $\mathrm{O}^{\prime}$-diethyl-S-benzylthiolophosphate) の抗菌作用に拈いて作用点が細胞壁合成系にあること を確認するため, 数種の Kitazin 類縁化合物を用い抗 菌活性と ${ }^{14} \mathrm{C}$-glucosamine の細胞壁画分へのとりこ み阻害活性との関連性を検討した。in vitroで菌系成 育阻害活性を有する化合物は ${ }^{14} \mathrm{C}$-glucosamine のとり こみ阻害活性を示し, 抗菌活性の認められない化合物 では阻害活性は示さなかった。抗菌活性化合物で処理 したいもち病菌菌系に UDP-N-acetylglucosamine が 蓄積していた。

（斎藤）

\section{4 発芽時細菌胞子の放射線感受性の变化}

Changes in Radiosensitivity of Streptomyces cacaoi Spores during Germination

C. Nagatsu, A. Matsuyama: Radiobiol. Lab., Inst. of Phys. and Chem. Res., Yamato-machi, Saitama, Agr. Biol. Chem., 34, (6) 860 9 (1970) 細菌胞子の発芽時に打ける放射線感受性の変化を熱 感受性扣よび核酸, タンパク合成との関連において榆 討するため, 発芽時の放線菌胞子に $\gamma$ 線を $1 \sim 4 \times 10^{4}$ rad 照射し, ${ }^{3} \mathrm{H}$-thimidine, ${ }^{3} \mathrm{H}$-uridine または ${ }^{14} \mathrm{C}$ Phe を含む培地で培養した。発芽処理 100 ～110分後に $\gamma$ 線感受性の高い時期があり, これは熱感受性の高い 時期と異なる。 $\gamma$ 線と紫外線とに対する感受性変化の パターンは異なる。 $\gamma$ 線扣よび紫外線感受性変化のパ ターンを核酸, タンパクの合成, 耐熱性および outgrowth との関連性において示すことができた。

（斎藤）

\section{5 放射線照射によるジャガイモの褐変現象}

Tissue Browning of Potato Tubers Induced by Gamma Irradiation

M. Ogawa, I. Uritani: Div. of Metabolic Regulation, Inst. for Biochem. Regulation, Fac. of Agr. Nagoya Univ., Agr. Biol. Chem., 34, (6) $870 \sim 7$ (1970)

収穫 8 日，1 か月扎よび 3 か月後のジャガイモに 線を10，20および50 krad 照射し， $25 \sim 26^{\circ} \mathrm{C}$ に貯蔵し た。その結果収穫 8 日扣よび 1 か月後の照射によって 塊茎組織内にしばしば褐変が見出され，この褐変現象 に伴ってポリフェノールオキシダーゼの一時的上昇, ポリフェノール化合物の増大，パーオキシダーゼの活 性上昇などが認められた。以上の事実から照射による 褐変を防ぐためには少なくとす収穫後 1 か月以上室温 に放置したのち，照射を行なうべきことが明らかとな った。

(斎藤)

\section{DNA 合成におよぼす showdomycin の影響}

Mechanism of Action of Showdomycin Part II. Effect of Showdomycin on the Synthesis of Deoxyribonucleic Acid in Escherichia coli

Y. Komatsu, K. Tanaka: Shionogi Res. Lab., Shionogi \& Co. Ltd., Osaka, Agr. Biol. Chem., 34, (6) 891 9 (1970)

Showdomycin (S) の作用機構を明らかにするため, 大腸菌を $2-{ }^{14} \mathrm{C}$-uracil, -thymine, -thymine-methyl${ }^{3} \mathrm{H}, \mathrm{Leu}-\mathrm{U}-{ }^{3} \mathrm{H}$ を含む培地で培養し, 核酸およびタン パクの比放射能を湘定した。低濃度のS RNA, タンパクの合成を阻害せずに DNA 合成を阻 害した。このとき uracil あるいは cytosine からの deoxycytidine phosphate $と$ deoxythimidine phosphate の形成は deoxyuridine phosphate および pyrimidine ribotides の形成にくらべてSにより強く阻 害されていた。 thimine 要求株による thymine から の deoxythimidine phosphates の形成はSに耐性を 示した。

(斎藤)

\section{7 セリンのスフィンゴ脂芘へのとりこみ}

Incorporation of Serine $-3-{ }^{-14} \mathrm{C}$ into Sphingolipid by Rat Liver Particulate

Y.Fujino, M. Nakano: Dept. of Agr. Chem., Obihiro, Zootechnical Univ., Obihiro, Hokkaido, Agr. Biol. Chem., 34, (6) 974 6 (1970)

ラット肝の $105,000 \times \mathrm{g}, 30$ 分間遠心で沈殿する顆粒 画分をパルミチル CoA, Ser-3-14C とともに培養し, スフィンゴ脂質にとりこまれる放射性の長鎖塩基の形 態について調べた。NADPH の存在下ではジヒドロ スフィンゴシンに比ベスフィンゴシンがよくとりこま れることが認められた。これはラット肝では, スフィ ンゴシンがジヒドロスフィンゴシンよりる多く生成さ れるか, あるいはスフィンゴシンの活性が高いためと 考えられた。NADPHの存在しない場合にはスフィン ゴシンのとりこみだけが見出された。
(斎藤)

\section{8 必須アミノ酸欠乏時の代謝変化}

Effect of Essential Amino Acid Deficiency on Protein Nutrition Part III. Incorporation of ${ }^{35} \mathrm{~S}-$ methionine into the Tissues of Rats Fed on Tryptophan-deficiency

H. Naito, M. Kandatsu: Dept. of Agr. Chem., Fac. of Agr., Univ. of Tokyo, Agr. Biol. Chem., 34, (7) 1078 83 (1970)

20\%酸化カゼインを含むトリプトファン欠乏食で成 熟ネズミを 9 日間飼育し, ${ }^{35} \mathrm{~S}$ メチオオンを腹腔内注 射 $1 ， 2 ， 4 ， 9$ 時間後の肝および筋中の遊離および 結合型メチオニンの比放射能を測定して, 20\%カゼイ ン食で並行飼育した対照動物のそれと比較した。その 結果, 肝タンパクの比放射能はトリプトファン欠乏に よって著しく高くなったが, 粗肝アルブミンや筋タン パクへのメチオニンとりこみには著しい差は認められ なかった。

(斎藤) 


\section{9 放射線抵抗性細菌の照射後の高分子合成}

Macromolecular Synthesis in Micrococcus radiodurans During-postirradiation Incubation

S. Kitayama, A. Matsuyama: Radiobiol. Lab., Inst. of Phys. and Chem. Res., Saitama, Agr. Biol. Chem., 34, (7) 1095 100 (1970)

放射線抵抗性細菌 M. radiodurans の細胞死亡高分

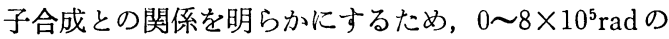
${ }^{60} \mathrm{Co} \gamma$ 線照射後の ${ }^{14} \mathrm{C}-ア$ ミノ酸のタンパク質へのと りこみおよび ${ }^{32} \mathrm{Pi} の$ RNA, DNA および polyphosphate 区分へのとりこみを測定した。タンパク質, RNA, DNA 合成は線量の増加とともに同じよ5に阻 害された。低線量照射後, クロラムフェニュール存在 下では DNA 鎖切断は修復されないので, DNA の損 傷の修復にタンパク質の合成が必要であるとすると高 線量照射後に見られるタンパク質合成の阻害は DNA 損傷の修復を阻害する。

（斑藤）
4720 Streptomyces verticillatus のナシムア ミド生合成

Biosynthesis of Cinamamide and Detection of Phenylalanine Ammonia-lyase in Streptomyces verticillatus

G.S. Bezanson, D. Desaty, A.V.Emes, L.C.Vining: Atlantic Regional Lab., Natl. Res. Council of Canada, Halifax, Nova Scotia, Can. J. Microbiol., 16. (3) $147 \sim 51$ (1970)

Streptomyces verticillatus でのシナムアミドの生

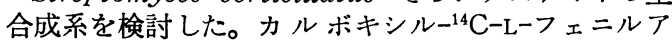
ラニンを菌の培養液とインキュベートするとシナムア ミドのカルボキシル基に取り込まれた。菌糸よりLーフ エニルアラニン,アンモニアーリアーゼ (EC. 4.3.1.5) が見出された。 ${ }^{14} \mathrm{C}$ でラベルされたシナムアミドの生 成速度はフェニルアラニン, アンモニアーリアーゼの合 成速度と一致していた。合成培地で生育させた場合, Lーフェニルアラニンを加えることによってのみシナム アミドを生成した。

(松崎)

\section{1 クロラムフェニコール生産菌の代謝}

Metabolism of Chloramphenicol by the Producing Organism

V.S. Malik, L.C. Vining: Dept. of Biol.,Dalhousie Univ., and Atlantic Regional Lab., Natl. Res. Council of Canada, Can. J. Microbiol., 16, (3) 173 $\sim 9$ (1970)

クロラムフェニコール生産菌の Streptomyces $13 \mathrm{~s}$ 株培養液に ${ }^{14} \mathrm{C}$ でラベルしたクロラムフェニコールを 添加すると, 放射能を有する物質として, $p$ 一ニトロフ エニルセリノール，N-アセチルーp-ニトロフェニルセ リノール, $p$-ニトロベンジルアルコールが生成した。 クロラムフェニュールは生育の停滞期を延長するとい う形で菌の生長を阻害し, また抗生物質の合成を阻害

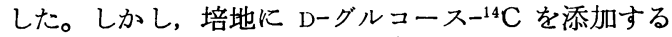
と, $100 \sim 200 \mathrm{mg} / l$ といら高濃度のクロラムフェニコ 一ル存在下でも放射能を有するクロラムフェニコール が生成した。

（松崎）

\section{2 昆虫付着有胞子細菌の生理学}

Physiology of Sporeforming Bacteria Associated with Insects. I. Glucose Catabolism in Vegetative Cells

L.A. Bulla, G. St. Jullan, R.A. Rhodes, C.W. Hesseltine: Northern Regional Res. Lab., Peoria, Illinois, Can. J. Microbiol., 16, (4) $243 \sim 8$ (1970) Bacillus thuringiensis, B. alvei, B. lentimorbus B. popilliae の増殖細胞に打けるグルコースの分解系 を放射呼吸活性测定法により検討した。グルコースー1 $2,3,4,6{ }^{-14} \mathrm{C}$ をおのおの培地に添加し $\mathrm{CO}_{2}$, 細胞, 培 地の ${ }^{14} \mathrm{C}$ を比較した。検討したどの株に打いてもラへ ルの位置による ${ }^{14} \mathrm{CO}_{2}$ としての回収率は $\mathrm{C}-4>\mathrm{C}-3>$ C-1>C-2>C-6 であり, Embden-Meyerhof-Parnas 回路が主要であることが明らかになった。B. lentimorbus は ${ }^{14} \mathrm{C}$ ラベルのグルタミン酸を酸化しないの で TCA 回路の酵素系が存在しないと考えられる。

（松崎）

\section{3 p-トルエンスルホン酸の分解}

The Degradation of $p$-Toluenesulfonate by a Pseudomonas

D.D. Focht, F.D. Williams: Dept. of Bacteriol., Iowa State Univ., Ames, Iowa, Can. J. Microbiol., 16. (5) $309 \sim 16$ (1970)

下水より単離したある種のPseudomonas 属細菌は 唯一の炭素源またはイオウ源として $p$-トルエンスル ホン酸を利用できるように適応していることが明らか になった。休止細胞を ${ }^{35} \mathrm{~S}-p$-トルエンスルホン酸とイ ンキュペートすると ${ }^{35} \mathrm{~S}$-硫酸塩の遊離に対する酸素の 組込みの比は分解中一定で，上澄みに ${ }^{35} \mathrm{~S}$ 一芳香族分解 中間体は検出されなかったが，あらかじめ細胞だけを インキュベートして括くと ${ }^{35} \mathrm{~S}$ 一中間体が 2 種遊離し た。 $1{ }^{14} \mathrm{C}-p$-トルェンスルホン酸とインキュベートす ると放射性の3-メチルカテュール, 酢酸塩, 非放射性 のピルビン酸が生成した。
（松崎）

\section{Aspergillus のマンニトール代謝}

Enzymatic and ${ }^{14} \mathrm{C}$-mannitol Studies of the Aspergillus Mannitol Metabolism

Wei Hwa Lee: Upjohn Comp., Kalamazoo, Michigan, Can. J. Microbiol., 16, (5) $363 \sim 7$ (1970)

ある種の Aspergillus 菌株 (UC 4177) ではグルコ 一スを基質にするとマンニトールを蓄積し，またその マンニトールを唯一の炭素源として利用でさる代謝系

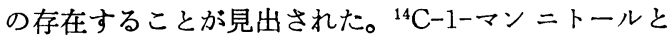

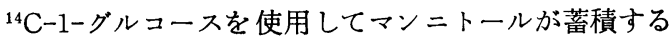
時期の酸化速度を ${ }^{14} \mathrm{C}-\mathrm{CO}_{2}$ の生成で見たところ, マ ンニトールとグルコースの酸化による $\mathrm{CO}_{2}$ の生成量 は23\%でマンニトールの酸化がグルコースの有無にか かわらず一定で, 蓄積と酸化が同時に進行しているこ とが明らかになった。

（松崎） 


\section{Pseudomonas aeruginosa のピオシアニ} 二分解

Pyocyanine Degradation by Apyocyanogenic Strains of Pseudomonas aeruginosa

Y. Azuma, Lloyd D. Witter: Dept. of Food Sci., Univ. of Illinois, Urbana, Ill., Can. J. Microbiol., 16, (5) 395 8 (1970)

Pseudomonas aeruginosa の突然変異株でピオシ アニン非生産性の 6 株は通常のピオシアニンを産生す る培養条件に拈いて，ピオシアニンを分解することが 見出された。菌株によって分解の程度は30 $80 \%$ と異 なっていた。 ${ }^{14} \mathrm{C}$ なラニンを培地に添加し， P. aeruginosa $\mathrm{F} 2$ によって産生した ${ }^{14} \mathrm{C}$ 一ピオシアニンを使 用して, 変異株の 5 B -275 株の細胞と $30^{\circ} \mathrm{C} 13$ 日間イ ンキュベートし，放射能の分布を見たところ，菌によ って，標識したピオシアニンはクロロホルムで抽出で きない程度に分解されていることが明らかになった。

（松崎）

\section{6 サルモネラ菌の放射線による滅菌}

Effects of Radiation Pasteurization on Salmonella I. Parameters Affecting Survival and Recovery from Chicken

Joseph J. Previte, Y. Chang, H.M.El-Bisi: Food Lab., United States Army Natick Lab., Natick,

Mass., Can. J. Microbiol., 16, (6) 465 71 (1970)

Salmonella typhimurium RIA 株をメチオニンを 添加した最小栄養培地で培養すると脳心臓抽出液 (brain heart infusion) で培養した場合に比べ ${ }^{60} \mathrm{Co}$ 照射に感受性の高い細胞が生じた。限界放射線量 $(D)$ は0.056ないし0.066Mrad で，Dは新鮮なまたは凍結 融解した鶏肉, あるいはオートクレーブまたは $2 \mathrm{Mrad}$ のイオン化放射線で滅菌した鷄肉上で $4{ }^{\circ} \mathrm{C} て ゙$ 細菌に照 射した場合で大きな差はなかった。Dは細菌が鶏肉上 にあるより増殖培地にあるほうが高かった。照射への 抵抗性は照射時の温度を下げることによって高まっ

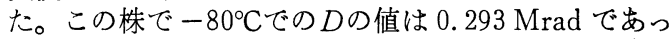
た。

\section{7 麦角菌のアルカロイド生合成}

Effect of Tryptophan on Alkaloid Biosynthesis in Cultures of a Claviceps species

L.C. Vining: Atlantic Regional Lab., Natl. Res. Council of Canada, Halifax, Can. J. Microbiol., 16, (6) $473 \sim 80$ (1970)

麦角菌 Claviceps $\mathrm{HL} \times 123$ 株の培養液にトリプト ファンを添加するとアルカロイドの合成が著しく増大 した。レートリプトファンー $\beta^{-14} \mathrm{C}$ を添加してその代謝 系を検討すると，対数増殖期の終り近く，アルカロイ ドの合成が始まるまでは菌糸中に標識アミノ酸が蓄積 された。それから細胞内のトリプトファンは速やかに アルカロイドに取り込まれ，培地に分泌された。アル カロイド合成時期に培地に与えた Lートリプトファン は最も効率よく取り込まれたがアルカロイドの総量は 多少増加した程度であった。

（松崎）

\section{9 ファージ感染と大腸菌 lac オペロン}

Expression of the Lac Operon in Escherichia coli Infected with RNA Phage R23

H. Watanabe, M. Watanabe: Dept. of Med. and Biochem., Univ. of Alberta, Edmonton, Alberta, Can. J. Microbiol., 16, (8) 713 7 (1970)

RNA ファージ R23 の感染した Escherichia coli でラクトースオペロンのうち透過醅素と $\beta$ ーガラクト シダーゼ遺伝子の発現はともに抑えられた。誘導物質 の透過に対する感染の影響を ${ }^{14} \mathrm{C}-\mathrm{IPTG}$ の取込みで検 討すると，感染と同時に ${ }^{14} \mathrm{C}-\mathrm{IPTG}$ を加えると最初の 5 分間は感染菌のほうがよく取り込み, また $\beta$-ガラク トシダーゼの生成量もやや多かった。 RNA 合成醉素 の変異株また RNase の存在下に打いて感染させても ${ }^{14} \mathrm{C}-\mathrm{IPTG}$ の取込々は野生株に感染させたときと変わ らなかった。これら酵素合成の抑制は $3^{\prime} 5^{\prime}$ 環状 AMP によって回復しなかった。 （松崎）

\section{8 プロトカテキュ酸オキシゲナーゼ合成}

Inhibition of the Induced Synthesis of Protocatechuate Oxygenase by $o$-Nitrobenzoic Acid

Karen F. Montgomery, Norman N. Durham: Dept. of Microbiol., Oklahoma State Univ., Stillwater, Oklahoma, Can. J. Microbiol., 16, (7) 609 $\sim 14$ (1970)

Pseudomonas fluorescens の産生する誘導醉素プロ トカテキュ酸オキシゲナーゼ (E.C. 1.13.1.3)の合成 は $o$-ニト口安息香酸により阻害された。阻害剤はこ の䤃素の活性を変化させることはなく，また細胞も死 ななかった。一方 Lートリプトファン ${ }^{14} \mathrm{C}$ および DLグルタミン酸-14C の細胞の熱トリクロル酢酸不溶性 画分への取込みは阻害剤により低下した。しかし放射 能標識了ミノ酸, 誘導物質, プロトカテキュ酸の細胞 への取込みは阻害しなかった。Escherichia coli の $\beta$-ガラクトシダーゼの合成も $o$-ニトロ安息香酸によ り阻害された。

(松崎)

\section{$4730 \boldsymbol{\beta}$-glucosidase の epoxideによる不活性化 \\ 機構}

Untersuchungen zum Wirkungsmechanismus glykosidspaltender Enzyme, $\nabla$. Markierung des aktiven Zentrums der $\beta$-Glucosidasen $\mathrm{A}$ und $\mathrm{B}$ aus dem Süßmandel-Emulsion mit ${ }^{3} \mathrm{H}-6$-Brom-6-deoxycondurit-B-epoxid

G. Legler: Org.-Chem. Inst. der Univ. Bonn, Hoppe Seyler's Z. Physiol. Chem., 351, (1)25 31 (1970) sweet almond emulsion $\curvearrowright \beta$-glucosidase A およびBは conduritol B epoxide および 6-bromo-6deoxy-conduritol-B-epoxide (I) により不活性化し, その不活性速度の $\mathrm{pH}$ 依存性はシグモイド型を示し た。epoxide 濃度と速度の関係は不活性化前に醉素と epoxide との間に Michaelis complex の生成を示し た。 ${ }^{3} \mathrm{H}-\mathrm{I}$ による醉素不活性化に批いて glucosidase A は Iを1.7，Bは0.98 mole/mole enzyme とりこみ, 両者に招いて放射性物質は $0.5 M$-hydroxylamine, $\mathrm{pH}$ $9.6 ， 35^{\circ} \mathrm{C}$ で完全に除去され，遊離した放射性物質は 6-bromocyclohexanepentol であった。 （斎藤） 


\section{1 酸性ムコポリサッカライドの代謝}

Untersuchungen zur Chemie der Arterienwand, $X V$. Stoff wechselheterogenität ${ }^{14} \mathrm{C}$ - und ${ }^{35} \mathrm{~S}$-markierter Glykosaminoglykane (sauer Mucopolysaccharide) bei in vitro-Inkubation

H. Kresse, E. Buddecke: Physiol.-Chem. Inst. der Univ. Münster, Hoppe Seyler's Z. Physiol. Chem., 351, (2) $151 \sim 6$ (1970)

ウシの胸部大動脈壁を U- ${ }^{14} \mathrm{C}$-glucose または ${ }^{35} \mathrm{~S}$ sulphateの存在下では12時間培養し, cetylpyridinium 化合物として酸性ムコポリサッカライドを分別した。 その酸性ムコポリサッカライドを hyaluranidase 拉よ び電気泳動により分解して ${ }^{14} \mathrm{C}-,{ }^{35} \mathrm{~S}$-標識 hyaluronate (I), chondroitin sulphate(II), dermatan sulphate(III), heparan sulphate (IV) を得た。ムコポリサッカライ ド中のそれらの割合は $[30, I 49$, III9.5, IV11.5 であった。 放射能比率と存在比率とから計算した相対的合成速度 は ${ }^{14} \mathrm{C}$ 標識の場合I1.9, III 1. 0, IV 0.9, II0.4であり, ${ }^{35} \mathrm{~S} の$



\section{2 培養がん細胞中の合成 DNA の分画法}

Elution neusynthetisierter DNA aus SäugetierZellen von Methylalbumin-Kieselgur-Säulen durch Guanidinthiocyanat

H. Probst: Physiol.-Chem. Inst. der Univ. Tübingen, Hoppe Seyler's Z. Physiol. Chem., 351, (2) $163 \sim 8(1970)$

腹水がん細胞を ${ }^{3} \mathrm{H}$-thymidine とともに 4 分，また ${ }^{14} \mathrm{C}$-thymidine とともに30時間培養し，これらの混合 物から DNA を遊離して，メチル化アルブミンカラム クロマトグラフィで食塩濃度 $0.3 \sim 1.6 M$, 続いてguanidine thiocyanate 濃度 $0 \sim 6 M$ の溶媒を用いて分画し た。さらに $6 M$ guanidine thiocyanate で温度を徐々 にあげることにより完全に分画した。食塩を含む溶媒 で溶出されない放射性 DNA が guanidine thiocyanate で完全に回収され，3つの新しい画分が得られた。こ れらの画分は新しく合成された DNA，扣そらく 1 本 鎖 DNA を相当量含有していた。

\section{3 ペントースリン酸回路の酵素作用}

Enzyme Pattern of the Pentose Phosphate Pathway in Ascites Tumor Cells and the Effect of Nucleoside Triphosphates on Its Enzyme Activities

K. Brand, K. Deckner and J. Musil: Max PlanckInst. für Ernährungsphysiol., Dortmund, Germany, Hoppe Seyler's Z. Physiol. Chem., 351, (2) 213 20 (1970)

がん細胞中のペントースリン酸回路の酵素活性パタ ーン拉よびそれらの酵素活性に及ばす nucleoside triphosphate の影響を明らかにするため, 肝蔵, 腎 臟, がん細胞の各酵素活性と nucleoside triphosphate 存在下て $1{ }^{-14} \mathrm{C}-, 6{ }^{-14} \mathrm{C}$-glucose と培養 し, ${ }^{14} \mathrm{C}$ の RNA, DNA へのとりこみを测定した。ペントースリ ン酸回路の相対的酵素量は組織が異なっても一定であ った。腎以外で transketolase はペントースリン酸回 路の limiting enzyme であった。ATP, GTPは glucose-6-phosphate dehydrogenase の競合的阻害剂 であった。

(斎藤)

\section{4 糖新生におよほす cortisol の影響}

Enzymaktivitäten und Substrakonzentrationen in der Rattenleber unter den Bedingungen der Cortisol-Gluconeogenese

B. Störmer, W. Janssen, H. Reinauer, W. Staib, S. Hollmann: Inst. für Physiol. Chem. der Univ. Düsseldorf, Hoppe Seyler's Z. Physiol. Chem., 351, (3) $296 \sim 304$ (1970)

糖新生に扣よぼす hydrocortisone (HC) の影響を 明らかにするため, 正常, 飢餓拉よび HC 投与ラット の肝の pyruvate (P) 代謝に関与する酻素活性および $1-{ }^{14} \mathrm{C}-\mathrm{P}$ を腹腔内注射し呼気 ${ }^{14} \mathrm{CO}_{2}$ を測定した。飢 餓時のみ acetyl-CoA 量, P-carboxylase, phosphopyruvate carboxylase 活性は増加し, P-kinase 活性が減 少した。HC 投与により血糖, 肝グリコーゲン量, in vivo の P酸化の阻害など糖新生の影響が明らかに認 められたが, P-carboxylase の活性増加以外飢餓にみ られた変化は増大せず, 逆に acetyl-CoA 含量, lactate/P 比は逆にわずか減少した。

\section{$4735 \mathbf{N}$-acylneuramine acid の合成}

Synthese von N-Acylneuraminsäuren, II. N-1- ${ }^{14} \mathrm{C}$ -Glykoloyl-N-Chloroacetyl-und N-Fluoroacetylneuraminsäure

R. Schauer, F. Wirtz-Peitz, H. Faillard: Inst. für Physiol. Chem. der Univ. Bochum, Hoppe Seyler's Z. Physiol. Chem., 351, (3) 359 64 (1970)

neuraminic acid- $\beta$-methylglycoside を $4-{ }^{14} \mathrm{C}-1,3-$ dioxylan-2,4-dione, chloroacetic および fluoroacetic anhydride でアシル化して N-1-14 $\mathrm{C}$-glycoloylneuraminic acid, N-chloroacetylneuraminic acid, Nfluoroacetylneuraminic acid を合成した。 N-acylneuraminic acid- $\beta$-methylglycosides 在下, $0.025 \mathrm{~N}$ 塩酸中で遊離の acylneuraminic acid に加水分解される。凍結乾燥 し脱脂したウシ唾液腺を $1 N$ 硫酸メタノール中で環流, 加熱することにより neuraminic acid- $\beta$-methylglycoside の游離法を単純 化した。またこれは水/dioxan から絬晶化され，収量 は80\%であった。 (斎藤)

\subsection{6 steroide の皮虞吸収について}

Steroide und Haut, III Perkutane Resorption von Androstenolon und Androstenolonsulfat

G.W. Oertel, P. Menzel: Expt. Endokrinol., Univ.-Frauenklinik, Mainz, Hoppe Seyler's Z. Physiol. Chem., 351, (3) 384 6 (1970)

$7 \alpha-{ }^{3} \mathrm{H}$-androstenolon $\left(4.95 \times 10^{6} \mathrm{Ipm}\right)$ または $7 \alpha$ ${ }^{3} \mathrm{H}$-androstenolonsulphate $\left(3.40 \times 10^{6} \mathrm{Ipm}\right) 10 \mathrm{mg}$ 含む $75 \%$ エタール $5 \mathrm{~m} l$ を25才の女性の下腿部の皮 膚上に扣き，溶液が消失してから24時間の尿を採取， 分析した。用いた ${ }^{3} \mathrm{H}$ 活性のそれぞれ $0.263 \%, 0.188$ $\%$ \% 24時間尿中に検出された。 ${ }^{3} \mathrm{H}$ 活性の尿中分布は それぞれ遊離 steroide $0.063 \%, 0.050 \%$, steroide sulphate $0.068 \%, 0.070 \%$, steroide glucuronide 0.132 \%,0.068\%であった。これらの結果は steroide sulphate は大部分，はじめに加水分解されてから，遊離 の steroide として吸収されることを示している。

（斎藤） 


\section{7 ウシ副腎の estrone 代謝}

Stoff wechsel von $4-{ }^{14} \mathrm{C}$-Östron in verschiedenen Gewebepräparationen und Zellfraktionen der Nebenniere des Rindes

W. Hoffmann, R. Kuppen, M. Breuer: Inst. für Klin. Biochem. der Univ. Bonn, Hoppe Seyler's Z. Physiol. Chem., 351, (3) 387〜96 (1970)

副腎およびその髄質，皮質ホモジネートを $4-{ }^{14} \mathrm{C}-$ estrone とともに培養し, 代謝産物をロ紙クロマトグ ラフィで分別し，化学的にまた結晶化して同定した。 代謝産物として $6 \alpha, 7 \alpha, 11 \beta, 14 \alpha, 15 \alpha, 16 \alpha$-hydroxyestrone (HE), estradiol-17 $\beta$, estriol が検出された。 放射能の $62 \sim 82 \%$ はエーテル可溶の遊離ステロイドと して見出された。水酸化物の中の主要な子のは $14 \alpha-$, $15 \alpha-\mathrm{HE}$ で, $11 \beta-\mathrm{HE}$ はわずかであった。水酸化物へ, の転換速度は全副腎19\%，皮質31\%，髄質11\%であっ た。水酸化の酵素系は招もにミトコンドリアに存在し ていた。 (斎藤)

\section{8 tRNA とアミノ酸転移酵素の種特異性}

Menschliche Proteinsynthese, VI. Species-Spezifität von Transfer-RNA und Aminoacyl-Transfer RNASynthetasen aus menschlichem Gewebe und $E$. coli Gesa Heller, Rolf Neth: Univ.-Kinderklinik Hamburg-Eppendorf und Arbeitsgruppe Biochem., MaxPlanck-Inst. für exptl. Med., Göttingen, Hoppe Seyler's Z. Physiol. Chem., 351, (4) 483〜8 (1970) ヒト扁桃执よび $E$. coli からの tRNA は同じ種か らの酵素画分によりアミノアシル化された。 ${ }^{14} \mathrm{C}-ア ミ$ ノ酸の 20 種を用いてアシル化した場合, tRNA を酵素 画分との種が異なると, 同一のときの35〜40\%しかア

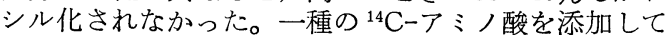
アシル化した場合, tRNA と酵素画分との種が異なる と, Proはほとんどとりこまれなかった。扁桃からの tRNA は E. coli の酵素画分により Arg, Cys, Gln, Glu, Gly, His, Leu, Ser, Trp, Tyr で一部アシル化 された。E. coli の tRNA ではArg, Trp で酔素画 分の相違は認められなかった。

(斎藤)

\section{9 種々の器官および腫瘍のタンパク合成活性}

Menschliche Proteinsynthese, VII. Aktivitäten von Transfer-RNA, Aminoacyl-Transfer-RNA-Synthetasen und Ribosomen aus verschiedenen Organgeweben und Tumoren

Gesa Heller, Rolf Neth: Univ.-Kinderklinik Hamburg-Eppendorf und Arbeitesgruppe Biochem., Max-Planck Inst. für exptl. Med., Göttingen, Hoppe Seyler's Z. Physiol. Chem., 351, (4) 489 500(1970)

${ }^{3} \mathrm{H}$ または ${ }^{14} \mathrm{C}$ アミノ酸を用いて in vitro で amino acyl-tRNA 合成を調べた結 果，扁桃，脾，副腎の間 には器官特異性は認められなかった。扁桃の acyl 化 酵素は腫演の酵素と同様に腫瘍 tRNA を高く acyl 化 した。逆に腫瘍の acyl 化酵素は扁桃または脾 tRNA をそれぞれの器官の酵素ほぞ高くは acyl 化しなかっ た。 tRNA の acyl 化される程度は扁桃, 脾, 副腎の 間で差はみられなかった。腫瘍 tRNAの20種のア ミノ酸により acyl 化される量は正常 tRNA のそれよ り 54 〜2\%高い。種々の器官, 腫瘍リボゾームの ${ }^{3} \mathrm{H}$ leucyl-tRNA 結合能力に差はなかった。 (斎藤)

\section{0 ヒト赤血球の pentose phosphate 代謝}

Bedeutung und Regulation des PentosephosphateWeges in menschlichen Erythrozyten, I. Versuche mit normalen Erythrozyten

K. Brand, P. Arese, M. Rivera: Max-Planck-Inst. für Ernährungsphysiol., Dortmund und Inst. di Chim. Biol. dell' Univ. Torino, Italian, Hoppe Seyler's Z. Physiol. Chem., 351, (4) 501 8 (1970)

ヒト赤血球のグルコース $(\mathrm{G})$ 代謝に打ける pentose phosphate 系(I) の寄与を Gの消費, 乳酸およびピル ビン酸の生成拈よび $1^{-14} \mathrm{C}-, 6^{6-14} \mathrm{C}-, \mathrm{U}-{ }^{14} \mathrm{C}-\mathrm{G}$ から生 成した $\mathrm{CO}_{2}$ の放射能を測定して検討した。正常赤血 球では pH7.6で約 $7 \%$ がIを，93\%が解糖系を経て 分解される。 $\mathrm{pH} 6.8$ では解糖系は約 $45 \%$ まで減少し

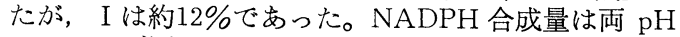
でほとんど同じであった。メチレンー青の存在に拉い てGはほとんど完全に I を経て代謝された。正常赤血 球ではIに执いて recycling は扰こらなかった。

(斎藤)

\section{1 ヒト赤血球の pentose phosphate 代謝}

Bedeutung und Regulation des PentosephosphateWeges in menschlichen Erythrozyten, II. Versuche mit Erythrozyten mit einem Glucose-6-phosphateDehydrogenase-Mangel

K. Brand, P. Arese, M. Rivera: Max-Planck-Inst. für Ernährungs-physiol., Dortmound und Inst. di Chim. Biol. dell' Univ. Torino, Italian, Hoppe Seyler's Z. Physiol. Chem., 351, (4) 509 14 (1970) glucose-6-phosphate dehydrogenase を欠く赤血球 （正常活性の $2 \%$ ) に打けるグルコース(G)の代謝を前 報 ${ }^{1)}$ 之同様の方法で $1-{ }^{14} \mathrm{C}-, 6-{ }^{14} \mathrm{C}-, \mathrm{U}-{ }^{14} \mathrm{C}-\mathrm{G}$ を用い てしらべた。 pH 7.6ではGはわずか $1.5 \%$ pentosephosphate 系(I)を経, $98.5 \%$ は解糖系(II)を経て代謝 された。 pH 6.8ではG 代謝は約60\%低下し，I の代謝 量は全 $\mathrm{G}$ 代謝の 5 〜 $6 \%$ に増加した。NADPH生成量 は両 $\mathrm{pH}$ でほとんど同じであった。メチレン青添加に よる I 代謝量の促進は非常にわずかで $1.5 \%$ が $2.5 \%$ に なった程度である。 Physiol. Chem., 351, (4) 501 (1970)
1) Hoppe Seyler's Z (斎藤)

\section{2 植物 ferredoxin の構造研究}

Untersuchungen zur Struktur des Pflanzenferredoxins

E. Bayer, D. Josef: Chem. Inst. der Univ. Tübingen und Chem. Dept., Univ. of Houston, Texas, Hoppe Seyler's Z. Physiol. Chem., 351, (4) 537〜 43 (1970)

アポ ferredoxin から $\mathrm{Na}_{2}{ }^{35} \mathrm{~S}$ を用いて ${ }^{35} \mathrm{~S}$ ferredoxin（I）を調製した。I の labile $\mathrm{S}$ および Fe は 2,2'-dipyridyl, トリクロロ酢酸扎よび triphenyl phosphine でもって分離された。これらの種々の条件 下で Feは Fe(II) または Fe(II) として, labile S は $\mathrm{S}^{2-}$ または $\mathrm{S}^{0}$ として反応した。I の活性中心におい て Fe またはSにとって不連続の酸化状態は考えられ なかった。活性中心のすべての酸化還元成分, すなわ ち labile $\mathrm{S}, \mathrm{Fe}$, システインまたはシスチン基の酸化 状態を測定することによって全活性中心の全酸化状態 を表わせることがわかった。 
4743 セリン tRNA の I 修飾について

Zur Modifizierung serinspezifischer TransferRibonucleinsäure durch Jod

R. Hirsch, H.G. Zachan: Inst. für Physiol. Chem. und Physik. Biochem. der Univ., München, Hoppe Seyler's Z. Physiol. Chem., 351, (5) 563 6 (1970)

Fittler \& Hall ${ }^{1)}$ の isopentenyladenosine によりヨ ウ素化された酵母 tRNA ${ }^{\text {ser }}$ についての知見を確認, 発展させた。高純度の酵母 tRNA ${ }^{\text {ser }}$ をヨウ素化する

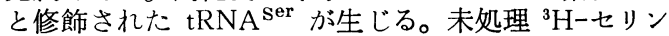

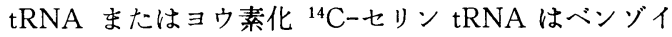
ル化 DEAE cellulose クロマトグラフィでそれぞれ異 なる単一ピークとして認められた。ヨウ素化によりア ミノアシル化の割合扣よび速度は変化しなかったが, リボゾームへのコードンに特異的な結合は約 $1 / 3$ 低下し た。この結果から $\mathrm{tRNA}^{\mathrm{ser}}$ の anticodon 部分の構造 変化が起こっているものと推测した。 1) Biochem. Biophys. Res. Commun., 25, 441 （1966）（斎藤）

\section{4 胚各期の tRNA 分布の差異について}

Differences in Ribonucleic Acid Populations of Amphibian Embryos Measured by the Hybridization Method

H. Jantzen, Jean-Marie Gasc, H. Tiedemann: Inst. für Physiol. Chem., Freie Univ., Berlin, Hoppe Seyler's Z. Physiol. Chem., 351, (5) 579 87 (1970)

胚の各時期の RNA 分布の差を検討するため, Xenopus laevis の胞胚期, 腸肧期および tail bud 期の ${ }^{3} \mathrm{H}$-uridine 標識执よび非標識 RNA を Xenopus DNA と 2 段階にハイブリッドさせた。 tail bud 期に 合成される mRNA の多くは腸肧期にも見出された。 しかし両期のRNAの量的構成は異なっていた。DNA が飽和されない条件下で標識された tail bud 期 RNA を用いての競合実験に括いて, 腸胚期 RNA に比して tail bud 期 RNA は強く競合した。これはおすに量 的差異によるものであろう。

\section{5 ムラサキツュクサで測定した RBE}

Relative Biological Efficiency of $14.1 \mathrm{MeV}$ Fast Neutrons and ${ }^{137} \mathrm{Cs}$ Gamma Rays in the Stamen Hairs of Tradescantia reflexa RAFIN

Ichikawa, S.: Lab. Genet., Fac. Agr., Kyoto Univ., Kyoto, Japan. J. Genetics, 45, (3) 205 16 (1970)

花色についてへテロなムラサキッュクサに 31〜141 $\operatorname{rad}$ の $14.1 \mathrm{MeV}$ の速中性子と $144 \sim 362 \mathrm{rad}$ の ${ }^{137} \mathrm{Cs}^{-}$ 子線を照射して雄芯系の平均細胞数, 生長停止した雄 芯系の割合, 雄芯系の生長, 1 系あたりの変異数, 変 異細胞の割合などを基準に両放射線の生物効果比を求 めた。それぞれの測定形質について14.1 MeV 速中性 子の生物効果比は $3.95,3.50,3.41,5.05,4.82$ となり, これら生物効果比の值は他の高等植物, 主として乾燥 種子照射から求めた值よりも非常に低い值となってい る。この差の原因としては含水量, 線量率の要因が考 えられる。

(田野)

\section{6 前漫清処理のコムギ種子での RBE}

Relative Biological Efficiency of $14.1 \mathrm{MeV}$ Fast Neutrons and ${ }^{137} \mathrm{Cs}$ Gamma Rays in the Pre-soaked Seeds of Triticum boeoticum Boiss and Its Autotetraploid

Ichikawa, S.: Lab. Genet., Fac. Agr., Kyoto Univ., Kyoto, Japan. J. Genetics, 45, (3) 217 24 (1970)

2 倍体のコムギ (Triticum boeoticum) とその同質 4 倍体の種子を $20^{\circ} \mathrm{C} 14$ 時間水に浸漬して $14.1 \mathrm{MeV}$ 速 中性子120〜750 rad, ${ }^{137} \mathrm{Cs}-\gamma$ 線 $290 \sim 1,750 \mathrm{rad}$ を照射 した。生物効果比は照射31日後の幼植物の草丈，49日 後の生体重, 乾物重量で比較した, ${ }^{137} \mathrm{Cs} \gamma$ 線に対する $14.1 \mathrm{MeV}$ 速中性子の生物効果比の值は, 草丈減少, 生体重, 乾物重についてそれぞれ3.12,3.48, 3.52で同 質 4 倍体でみたこれらの值はそれぞれ2.66,2.80,2.74 となった。これらの值はいずれす先に乾燥種子で得ら れた值よりす明らかに低く水分含量が生物効果比の值 を変えることがわかった。 (田野)

\section{Mycoplasma laidlawii の脂诈代謝}

Metabolic Turnover of the Polar Lipids of $M y$. coplasma laidlawii Strain B

Ronald N. McElhaney, Mark F. Tourtellotte: Dept. of Animal Disease, Univ. of Connecticut, Storrs, Conn., J. Bacteriol., 101, (1) 72 76 (1970)

Mycoplasma laidlawii B の 膜極性脂質の脂肪酸 アシル基は, 菌を ${ }^{14} \mathrm{C}$ ーパミチン酸あるいはオレイン 酸あるいはリノール酸存在下に増殖した場合に標識さ れた。非放射性の脂肪酸を含む培地で放射能で標識し た細胞をインキュベートしても，増殖と脂質合成が続 くにもかかわらず膜極性脂質の放射能は減少しなかっ

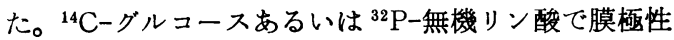
脂質のグルンース，リン酸部分を標識し，脂肪酸と同 様な方法でインキュベートしてる放射能は減少しなか った。増殖細胞でこれら脂質はほとんど代謝されない と考えられる。 


\section{Bacteroides melaninogenicus の脂質}

Lipids of Bacteroides melaninogenicus

Victor Rizza, Anne N. Tucker, David C. White: Dept. of Biochem., Univ. of Kentucky, Med. Center, Lexington, Ky., J. Bacteriol., 101, (1) 84 $\sim 91$ (1970)

Bacteroides melaninogenicus を $\mathrm{H}_{3}{ }^{32} \mathrm{PO}_{4}$ を含む 培地で培養し細胞より脂質を抽出した。クロロホルムー メタノール抽出で 97\%の脂質が分離された。抽出さ れた脂肪酸の $96 \%$ はリン脂質に存在した。脂質をケイ 酸口紙で 2 次元ペーパークロマトグラフィをしてオー トラジオグラムをとるとフォスファチジン酸, フォス ファチジルセリン，フォスファチジルェタノールアミ ンが主成分でフォスファチジルグリセロール，カルジ オリピンを含む株もあった。特殊のフォスフォスフィ ンゴリピドとして 3 種の脂質が脂質リン酸の 50 ～70\% 含まれていた。

(松崎)

\section{Neisseria meningitidis のコハク酸代謝}

Catabolic Activities of Neisseria meningitidis:

Utilization of Succinate

Emilio Weiss: Dept. of Microbiol., Naval Med. Res. Inst., Bethesda, Md., J. Bacteriol., 101, (1) 133 7 (1970)

Neisseria meningitidis の 休止細胞を $1,4-{ }^{14} \mathrm{C}-コ$ ハク酸, $4-{ }^{14} \mathrm{C}-$-マレン酸, $1,4-{ }^{14} \mathrm{C}$-フマル酸 とイン キュベートしても呼吸打よび $\mathrm{CO}_{2}$ の産生は促進され なかったが， $\alpha$ なトグルタール酸とアスパラギン酸の 混液，グリコールまたはグルタミン酸をインキュベー トのさい添加するとこれらのジカルボン酸は容易に代

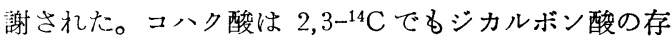
在下で同程度代謝された。コハク酸の取込みはグルタ ミン酸添加の場合他のジカルボン酸より促進された が，ジニトロフェノールにより完全に阻害された。

(松崎)

\section{Streptococcus faecalis $の \mathbf{K}^{+}$イオン蓄皘}

Extrusion of Sodium and Hydrogen Ions as the Primary Process in Potassium Ion Accumulation by Streptococcus faecalis

F.M. Harold, J.R. Baarda, E. Pavlasova: Div. of Res., Natl. Jewish Hosp., Denver, Colorado, J. Bacteriol., 101, (1) 152 9 (1970)

Streptococcus faecalis のグルコース代謝細胞は $\mathrm{H}^{+}$ 扣よび $\mathrm{Na}^{+}$の排出と同時に $\mathrm{K}^{+}$を蓄積するが，この 透過機構について検討した。グルコース代謝細胞内の $\mathrm{Na}^{+}$はアンモニア，ジェチルアミン，トリスアミノメ タンなどの窒素カチオンの存在下で容易に加えた $\mathrm{Na}^{+}$ と置換したが $\mathrm{K}^{+}$は完全に細胞内レベルは変わらなか った。 ${ }^{22} \mathrm{Na}$ と $\mathrm{Na}^{+}$の置換はグルコース存在時のみ見 られ $10 \mathrm{~m} M \mathrm{~K}^{+}$で阻害された。 $\mathrm{K}^{+}$蓄積能の低下した 突然変異株では添加した ${ }^{42} \mathrm{~K}$ は細胞内の $\mathrm{K}$ と野生株よ り速やかに置換された。2 株のうち一方は $\mathrm{K}^{+}-\mathrm{H}^{+}$置 換の欠失, 他方は $\mathrm{K}^{+}-\mathrm{Na}^{+}$置換の変化であった。

(松崎)

\section{2 ペニシリナーゼ合成の制御}

Regulation of Penicillinase Synthesis: Evidence for a Unified Model

John Imsande: Dept. of Biol., Case Western Reserve Univ., Cleveland, Ohio, J. Bacteriol., 101, (1) $173 \sim 80$ (1970)

Bacillus cereus 569株の産生するペニシリナーゼの 誘導のカイネティックスを検討した。ペニシリナーセ の合成速度の増加は誘導物質としてベンジルペニシリ ンを添加後 30 秒以内に見られるが最大速度に達するの には30分かかった。 ${ }^{14} \mathrm{C}$-ベンジルペニシリンの細胞へ の結合を見ると細胞あたり約 1,000 分子の ${ }^{14} \mathrm{C}$-ペニシ リンが結合していることが明らかになった。結合性を 検討するため細胞に ${ }^{14} \mathrm{C}$-ベンジルペニシリンを結合さ せ，プロトプラストを作ると75\%がその画分に残って いた。ペニシリナーゼメッセンジャー RNA の半減期 は 2 分であった。

(松崎)

\section{3 大腸菌 RNA への5-ジアソウラシル取込み}

Incorporation of 5 -Diazouracil-2-14 $\mathrm{C}$ into Ribonucleic Acids of Escherichia coli during Division Inhibition

Edward Previc, George Fister: Dept. of Microbiol., College of Med., Univ. of Florida, Gainesville, J. Bacteriol., 101, (1) 188 95 (1970)

放射性のジアゾウラシル (DZU-2- $\left.{ }^{14} \mathrm{C}\right)$ が Escherichia coli B の酸不溶性画分に速やかに取り込まれ た。RNA に放射能のすべてが回収された。添加放射 能の 40〜 50\%がジアゾウラシルの細胞分裂阻害または それに近い濃度で取り込まれた。あらかじめ培地中で DZUをインキュベートして扰くと取込みのレベルお よび分裂阻害の結果として生ずる繊維状細胞形成能が 低下した。活性のある DZU が不安定で異性体が生成 する結果と考えられる。DZU の形で RNA の放射能 標識部分には回収されないので加水分解して5-ヒドロ キシウラシルになるなどの変化が考えられる。

\section{B. subtilis およびファージへのウリジン \\ 取込み}

Incorporation of Uridine into Bacillus subtilis and SPP1 Bacteriophage

Sergio Barlati: Dept. of Gen., Stanford Univ. School of Med., Stanford, Calif., J. Bacteriol., 101, (1) $330 \sim 2$ (1970)

B. subtilis への DNA ファージ SPP1 感染後の RNA 合成を uridine $-5-^{3} \mathrm{H}$ の取込みで見たところ放 射能が成熟ファージ核酸中に見られた。この現象につ いて検討するため SPP1 ファージ感染と同時に ${ }^{3} \mathrm{H}$ 一ウ リジンと ${ }^{14} \mathrm{C}$-チミシシンを添加し, 完全に溶菌後, フ アージを取り出すと ${ }^{3} \mathrm{H}$ のカウントは ${ }^{14} \mathrm{C} に 一$ 致, す なわち DNA 中に見い出された。 ${ }^{3} \mathrm{H}$ 牤よび ${ }^{14} \mathrm{C}$ の挙 動はDN アーゼに対する感受性, アルカリに対する抵 抗性により DNA であることが確かめられた。 $B$. subtilis をファージと同様二重標識すると ${ }^{3} \mathrm{H}$ ーウリシ ンの放射能は DNA のシチジン中に見出された。 


\section{5 ファージ感染後の Coding の抑制}

In vivo Suppression of Coding Associated with Bacteriophage-Induced S-Adenosylmethionine $\mathrm{Hy}$ drolase

P.W.Siersma, S. Lederberg: Dept. of Biol. and Med. Sci., Brown Univ., Providence, J. Bacteriol., 101, (2) $398 \sim 407$ (1970)

$\mathrm{T}_{3}$ ーファージ感染後S-アデノシルメチオニン(SAM) ーヒドロラーゼが誘導されることはメチル ${ }^{14} \mathrm{C}-\mathrm{SAM}$ よりメチル-14C-メチルチオアデノシンの生成するこ とで明らかだが，そのさい合成されるリボゾームおよ び転移. RNA のメチル化の程度を ${ }^{14} \mathrm{C}$-ウラシルとメ チルーㄱーメチオニンの二重標識をして調べると, 非感 染菌で50\%が減少していた。リボゾームの完成または 安定性は変わらないこと, アルカリフォスファターゼ の変異の見かけ上の復帰がファージ感染によって増加 することなどより, SAMーヒドロラーゼは翻訳過程の 安定性に寄与していると考えられる。

（松崎）
4756 Myxococcus xanthus のミクロシストの代謝

Stable Messenger Ribonucleic Acid and Germination of Myxococcus xanthus Microcysts

W. Scott Ramsey, Martin Dworkin: Dept. of Microbiol., Univ. of Minnesota, Mineapolis, Minn., J. Bacteriol., 101, (2) 531 40 (1970)

変形菌 Myxococcus xanthus のミクロシストに拉 计る発芽, タンパク質合成, RNA 合成を調べた。誘導 後 2 時間で, アクチノマイシンDの存在下で発芽, $\mathrm{L}$ ロイシン $-1-{ }^{14} \mathrm{C}$ の酸不溶性物質への取込みでみたタ ンパク質合成，ウリジン $-5-{ }^{3} \mathrm{H}$ の同様画分への取込み で見た RNA 合成のいずれる阻害された。誘導後 6 時 間たつとアクチノマイシンDにより RNA 合成以外の 阻害が著しく低くなった。 ${ }^{3} \mathrm{H}$ 標識のアクチノマイシ ンDを使用して DNA への結合量を比較しても差はな


標識 RNA は増殖細胞のそれより安定であった。

（松崎）

\section{7 培養細胞のタンパク，リピッドの合成}

Synthesis of Glycoprotein, Glycolipid, Protein, and Lipid in Synchronized L-5178Y Cells

Bosmann, H.B., R.A. Winston: Dept. Pharmacol., Univ. Rochester, Med. School, Rochester, New York, J. Cell. Biol., 45, (1) 23〜33 (1970)

マウスの培養細胞系 L-5178 Y で glycoprotein, glycolipid, protein, lipid の合成を細胞周期との関係

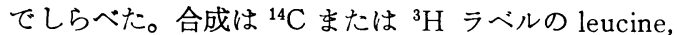
choline, fucose, glucosamine, thymidine の30分パル スラベルで測定した。細胞質 protein はS 期に最高で 全周期にわたり合成がみられるがM期で抑制される。 glycoprotein は protein へほぼ同様に合成される。浸 出性 protein は全期にわふって合成があり $\mathrm{S}$ 期後期と $\mathrm{G}_{2}$ 期が高い, 浸出性 glycoprotein も同様である。細 胞質 lipid は glycolipid とともに $\mathrm{G}_{2}, \mathrm{M}$ 期に合成さ れるが $\mathrm{G}_{1}, \mathrm{~S}$ 期には合成がない。

\section{8 ヒマ胚乳の glyoxysome}

Developmental Studies on Glyoxysomes in Ricinus Endosperm

Gerhardt, B.P., H. Beevers: Dept. Biol. Sci., Purdue Univ., Lafayette, Ind., J. Cell Biol., 44, (1) $94 \sim 102$ (1970)

暗黒下に拈けるヒマの発芽時拈よび生育初期の胚乳 の glyoxysome とその関連酵素について研究した。 胚乳は半分にわけて ${ }^{14} \mathrm{C}$ または ${ }^{3} \mathrm{H}$-leucine でラベル した。glyoxysomesのタンパク含量は $2 \sim 4$ 日直線的 に増加し，しだいに減少する。しかし醉素活性は 5 日 目に最高となった。発芽の全期間を通じて isocitrate lyase 活性をるつ部分は glyoxysomes であるが, 初 期には全活性の多くが可溶性部分に得られた。maltose synthetase は4 日後に glyoxysomes にみられる。こ の酵素は試料作成中に glyoxysomes の破壊されるこ とで得られたもので酵素活性は glyoxysomes と関係 が深い。

\section{9 発生期ポリペプチドの分解}

Controlled Proteolysis of Nascent Polypeptides in. Rat Liver Cell Fractions I. Location of the Polypeptides within Ribosomes

Blobel, G., D.D.Sabatini: Rockefeller Univ., New York, J. Cell Biol., 45, (1) 130 45 (1970)

ラット肝藏細胞で in vivoでラベルした発生期ポリ ペプチドを含む遊離リボゾームをトリプシン，キモト リプシンの混合物で分解した。ショ糖密度勾配による 分析では，ポリゾームは低温下で 24 時間保たれたが mRNA のないリボゾームは 2 時間以内に完全に分解

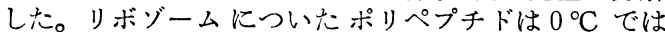
タンバク分解に対して部分的に抵抗性がある。発生期 ポリプペチド鎖にとりこまれた ${ }^{3} \mathrm{H}$ まは ${ }^{14} \mathrm{C}$ ラベル の leucine は $(50 \mu \mathrm{Ci} / \mathrm{m} l$ または $5 \mu \mathrm{Ci} / \mathrm{m} l) 3$ 分以

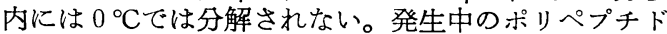
末端はリボゾームの構造から分解をらけないと考えら れる。

\section{0 サメの末梢血液細胞での生合成}

Macromolecular Synthesis in Dogfish Periferal Blood Cells

Pederson, T., S. Gelfant: Marine Biol. Lab., Woods Hole, Mass., J. Cell Biol., 45, (1) 183 7 (1970)

末梢血液細胞中での DNA, RNA, タンパクの合戊 をしらべるためにサメを用いて実験した。 ${ }^{3} \mathrm{H}$-thymidine, ${ }^{3} \mathrm{H}$-cytidine, ${ }^{3} \mathrm{H}$-leucine (比放射能1.9 2.0Ci/ mmole）でラベルした血液をオートラジオグラムなど の方法でしらべた結果, 循環しているリンパ球や赤芽 細胞では DNA, RNA およびタンパクの 合成がみら れた。しかし他の血液細胞では合成はみられない。赤 芽細胞は比較的安定な mRNA をもっている。この mRNA はアクチノマイシンDでの RNA 合成阻害後 のタンパク合成に無関係なもので末梢循環系は血液系 で 1 つの要素であることを示している。 


\section{RI 医学利用文献抄録集（44）}

3704 Internal Distribution and Absorbed (6)(7) Dose Calculations for Radioactive Indium Liver and Lung Scanning Agents V.A. Brookeman, et al.: Dept. of Radiol., Univ. of Florida College of Med., Gainsville, Fla., Amer. J. Roentgenol., 109, 735 41 (1970)

${ }^{113 m} \mathrm{In}$ ーコロイドの体内分布をラットを用いて調 べ, この結果を人体に応用して各藏器の被曝線量を求 めた。ラットでは投与後 $84 \%$ が肝に，9\%が血中に， $2 \%$ ぞその他の臟器に分布し, 肝よりの代謝は生物学 的半隇期 21 日, 血中からのそれは13時間であった。大 粒子の水酸化鉄 ${ }^{113 m} \mathrm{In}$ では $73 \%$ が肺に， $2 \%$ が肝に 捕捉される。 $3 \mathrm{mCi}$ の ${ }^{113 \mathrm{~m}} \mathrm{In}$ ーコロイドの人体被ばく は, 肝 1.3 , 脾 $0.17 \sim 0.42$, 骨ずい 0.71 , 睪丸 0.049 , 卵栄 0.050 , 全身 0.049 (ラド) である。水酸化鉄 $-{ }^{113 m} \mathrm{In}$ では, 肝 $1.0 \sim 1.8$, 肺 $0.12 \sim 0.18$, 全身 $0.033 \sim 0.049$ ラドである。

(79500)
3705 Transmission Scintigraphy in :- (7)(11)(12) the Evaluation of Subphrenic Abscess J.A. Volpe, et al.: Donner Lab., Univ. of Calif., Berkeley, Calif., Am. J. Roentgenol., 109, 733〜4 (1970)

Transmission シンチグラムが横隔膜下膿瘍の診断 に役立った 2 例が述べてある。

Transmission シンチグラムによって肺のシンチグ ラムが得られ，さらに $1 \mathrm{mCi}$ の ${ }^{99 m} \mathrm{Tc}$-コロイドによ って肝のシンチグラムが得られ，両者から右肺と肝と の間に space occupied lesion を知りこれから横踹 膜下膿瘍を知ることができるわけである。

(79473)

\section{Liver Scintigrams in Patients}

(7)(11) with Cancer T.P.Haynie, et al.: Dept. of Med., Univ. of Texas, M.D. Anderson Hosp., Houston, Tex., Cancer Bull., 22, 33〜6 (1970) ${ }^{198} \mathrm{Au}$ ーコロイドまたは ${ }^{99 m} \mathrm{~T}_{2} \mathrm{~S}_{7}$-コロイドによる肝ス キャンは肝悪性腫瘍の検出に有用な方法である。754 例に肝スキャンを実施した。このうち388例は ${ }^{198} \mathrm{Au}$ と

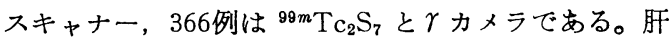
がん症例中, ${ }^{198} \mathrm{Au}$ で82\%に異常スキャン, $62 \%$ cold area をみた。 ${ }^{99 m} \mathrm{Tc}_{2} \mathrm{~S}_{7}$ では $81 \%$ に異常, 64\%に cold area をみた。これらの false negative 症例の大多数 は, $2 \mathrm{~cm}$ 以下の病巣を有し， $\gamma$ カメラやスキャナーで は解像しえなかったるのである。非腫瘍性疾患では ${ }^{198} \mathrm{Au}$ で70\%に異常スキャン，24\%に cold area を ${ }^{90 m} \mathrm{TC}_{2} \mathrm{~S}_{7}$ で59\%に異常スキャン，22\%に cold areaを みた。

(78891)
3707 Liver Gammaphotography: A

(7)(11) Clinical Review of 512 Cases J.F. Mangum, et al.: Univ. of Calif. Med. Center, San Francisco, Calif., Gastroenterol., 58, 973 (1970) Anger カメラと ${ }^{99 m} \mathrm{Tc}_{2} \mathrm{~S}_{7}$-コロイドを用いる gammaphotography はスキャンに比し, 単純で速く, 解 像力のよい肝影をうることができる。本法の利点を検 討するために 512 例について, 肝生検, 剖検などによ る組織診断との比較を行なった。剖検例に関しては, シンチフォトの所見と $91 \%$ 一致がみられた。また96 $\%$ 外科生検例, $67 \%$ 肝経皮的生検例, $84 \%$ の腹腔 鏡実施例でも一致をみた。これらの症例中 $32 \%$ はンン チグラムの異常にかかわらず肝機能は正常を示した。 316 例の 組織学的所見を得られなかった症例について はシンチグラムのみで判定を行なったが36\%で肝機能 所見より高度の異常を示した。

(78859)

\section{Indium-113m for Liver Scanning (7)(11)}

R. Vigneri, et al.: Inst. di Patologia Speciale Med. e Metodologia Clinica dell' Univ. di Catania, Italy, J. Biol. Nucl. Med., 13, 106 14 (1969)

著者らは, ${ }^{113 m}$ In の肝シンチグラフィへの導入はつ ぎの理由で正当化されると考えている。すなわち(1)被 曝線量の減少，(2)長い半減期の ${ }^{113} \mathrm{Sn}$ より，いつで もとり出しうる，(3)高い計数值のため統計誤差が小さ w。

23例の患者に41回の ${ }^{113 m} \mathrm{In}$ 一スキャンを行なった。 ${ }^{113 m}$ In のスキャンは注入後 2 時間以内に行ならべきで ある。 ${ }^{198} \mathrm{Au}$-コロイドと比較すると, ${ }^{113 m} \mathrm{In}$ では脾は より見やすくなり，正常人でも可視化しうる。スキャ ン時間す短縮しうる。

(79400)
3709 Liver Scanning: Analysis of 2,500 (7)(11) Cases of Amebic Hepatic Abscesses A. Cuaron, et al.: Unidad de Med. Nuclear, Hosp. General, Centro Med. Nacional, Mexico City, J. Nucl. Med., 11, 435〜9 (1970)

通常法と異なり，アメーバ膿瘍を肝シンチで見出す 最良の一回法は, 背面像である。2,500例に3, 379例の 肝スキャンを行なった。 $83.0 \%$ 1個の膿癔のみを有 し，17\%が 1 個以上の膿瘍を有していた。4, 286 例の 膿瘍が見出されたが, 最も多発した部位は, 右葉の外 側部(65.0\%), 後部(54.5\%), 上部( $41.6 \%)$ で, 左葉 はわずかに21.4\%であった。右側面スキャンで72. $2 \%$ の病巣が見出され, 前面像で92.8\%, 後面像では94.6 \%が描出された。前面, 側面像の組合わせは95.5\%の 病巣を描出し, 後面と右側面像の組合わせは97.1\%, 3 面像の組合わせは98.6\%を描出しえた。（78701） 


\section{Scintillation Scanning in the}

(7)(11) Diagnosis of Hepatic Abscess in Children R.E. O'Mara, et al.: Div. of Nucl. Med., Dept. of Radiol., Upstate Med. Center, State Univ. of New York, J. 'Pediat., 77, 211 5 (1970)

小児の肝膿瘍の確定診断を行なうために，いかに肝 スキャンを行ならかを説明するため 2 例の病症を記載 する。 ${ }^{89 m} \mathrm{Tc}_{2} \mathrm{~S}_{7}$-コロイド $1 \sim 3 \mathrm{mCi}$ を小児の年令と 体重に応じ, 静注, 3 方向を30分でスキャンした。小 児が重症のときまたは不隠で，非協力的のときには， スキャンは適当でなく， い。しかし通常著者らは, X線フィルムの上に重復し うる点より，等身大の肝シンチのほうを好んでいる。 そして検出能す Anger カメラより高い。（78993）
3711 The Binary Spleen: A Radio(7)(9) isotopic Scan Sign of Splenic Pseudocyst H.A. Pearson, et al.: Dept. of Pediat. \& Surg., Yale Univ. School of Med., J. Pediat., 77, 216〜20 (1970)

脾スキャンには, ${ }^{99}{ }^{m} \mathrm{~T} \mathrm{c}_{2} \mathrm{~S}_{7}$-コロイドのよい脾集積性: と低い被嚗線量のため，これを用いるのがよいと考え られている。脾の偽襄胞を有する 2 例の小呪に ${ }^{99 m} \mathrm{Tc}_{2} \mathrm{~S}_{7}$-コロイドスキャンを行なった。巨大な左上 腹部腫瘤中に, 2 個の別々の脾摄取部位が見出された。 著者らはこれを“binary spleen” sign と呼び, 変胞の 術前診断に有用であると考えている。脾スキャンは, 安全, 迅速, かつ有用なテストで, 通常のX線像では 得られない情報を与えるものである。

(78994)

\section{The Scintigraphic Appearance of (7)(11)}

the Liver after Operation F.J. Siber, et al.:

Dept. of Diagnostic Radiol. \& Surg., Lahey

Clin. Bull., 19, 71〜6 (1970)

肝障害 (良性霔胞, 単発転移性腫瘍扣よび右葉の血 管腫）に肝剔を行なった 3 症例について， ${ }^{198} \mathrm{Au}$ ーコロ イト $100 \mu \mathrm{Ci}$ を投与， 5 インチスキャナーを用い，そ の「再生過程」を追求した結果をのべている。背臥位 扣よび右側面よりスキャンを行なった。再生過程はい ずれの症例でも, 非常によく追求し得, この目的にも スキャンの有用であることを知った。 ${ }^{99 m} \mathrm{~T}_{2} \mathrm{~S}_{7},{ }^{113 m} \mathrm{In}-$ コロイド, ローズベンガルもこの目的に適していると 考えられる。

(78666)
3713 Hepatic Scanning and Angiography (7)(11) L.M. Freeman, et al.: Dept. of Radiol., Albert Einstein College of Med., Yeshiva Univ., N.Y. State J. Med., 70, 2007〜9 (1970)

肝スキャンと, 腹腔動脈造影法は, 肝疾患の診断に たがいに，補助的な診断法である。

肝スキャンは ${ }^{198} \mathrm{Au}$-コロイドなどの投与により容 易に実施できるが大きな制約は $2 \mathrm{~cm}$ 以下の 病巣を検 出しえぬことである。特異的な組織診断はできない。 腹腔動脈造影法は, スキャンの陽性像をさらに明確化 し, $2 \mathrm{~cm}$ 以下の 病巣の検出もできる。血管性, 非血 管性病巣の検出, 肝内病巣による圧排, 肝外傷による 出血も鑑別しうる。本法を行ならにさいし, 重要なこ とは, 技術的レベルと経験, 高価な機器を要すること である。ヨウ素過敏症には不適応である。（78934）
3714 The Mark II Scanner: A Compact (7)(2)(17) Device for Multiple-View and Section Scanning of the Brain D.E. Kuhl, et al.:

Dept. of Radiol. of the School of Med. and Hosp. of Univ. of Penn., Philadelphia, Radiol., 96, 563〜70 (1970)

4 検出器を配置したスキャニング装置を用いること により，多方向からの脳シンチグラムが同時に得られ るばかりでなく，これらの情報を電算機で解析するこ とにより断層シンチグラムをる行ならことが可能であ る。

(79632)
3715 The Application of Liver Scan to (7)(11) the Diagnosis of Esophageal Varices A.I. Rogers, et al.: Dept. of Med., Div. of Gastroenterol., Univ. of Miami School of Med., Miami, Fla., S. Med. J., 63, 950〜3 (1970)

${ }^{198} \mathrm{Au}$-コロイドの iv 注入による肝外網内系の描出 と食道静脈瘤の存在との間には高度の相関がみられ る。このことは, 門脈高圧症の診断に括ける肝スキャ ンの価值を示唆するるのである。肝硬変症の 49 例にス キャンを実施した。スキャン・スコアを定めて分類の 結果, ${ }^{198} \mathrm{Au}$ の肝摄取の減少, 肝外摂取の増加と食道 静脈瘤の間には77\%の一致がみられた。この方法の一 致は全症例について59\%であった。

(79395) 
3716 Thyroid Function Tests: The

Chemical Thyroid Profile A. Anido, et al.: Chem. Dept. Dade Div., Amer. Hosp. Supply Corporation Miami, Fla., Amer. J. Med. Technol., 36, 317 26 (1970)

$\mathrm{T}_{4}$ とその TBG, TBPA との結合性括よび全ホル モン濃度に対する遊離型または活動型 $\mathrm{T}_{4}$ との関係が 検討され, さらに PBI, BEI の測定法, 湿式灰化法が 詳細に検討された。

また異常值を示す筷患扰よびその測定に干涉する有 機物の污染が検討され, free thyroxine index (FTI) が診断上有用であることが強調された。

(79616)

\section{Recognition and Resolution of}

Errors in the Radioisotopic Assay of

Serum Vitamin $\mathbf{B}_{12}$ E.P. Frenkel, et al.:

Dept. Internal Med., Univ. of Texas Southwestern Med. School, Dallas Tex., Amer. J. Clin. Pathol., 53, 891 903 (1970)

血清 $\mathrm{B}_{12}$ の isotopic assay の問題点を論じている。 assay は競合阻害に基づいている。血清タンパクから 内因性 $\mathrm{B}_{12}$ を分離し, これに $\mathrm{B}_{12}$ 結合部位をるつ物質 一定量と ${ }^{57} \mathrm{Co}-\mathrm{B}_{12}$ の 既知量を加える。 ${ }^{57} \mathrm{Co}-\mathrm{B}_{12}$ と内 因性 $\mathrm{B}_{12}$ はこの結合部位を競うことになるので検体中 の $\mathrm{B}_{12}$ 含量少なければ ${ }^{77} \mathrm{Co}-\mathrm{B}_{12}$ の結合率が高くなる。 $\mathrm{B}_{12}$ 含量は標準曲線に照らして求められる。しかし内 因性 $\mathrm{B}_{12}$ の分離が完全か，用いる結合物質によるバラ ツキ, ${ }^{57} \mathrm{Co}-\mathrm{B}_{12}$ の純度等が問題となる。標準結合物質 としてはミリポアーフィルターを通した正常血清がい ちばん良い。電気泳動とオートラジオグラフィで分析 すると ${ }^{57} \mathrm{Co}-\mathrm{B}_{12}$ の純度は高い。

$(78670)$

\section{Predictability of Red Cell Volume}

from RISA Blood Volume M.L. Nusynowitz, et al.: Radioisotope-Endocrine Clinic, William Beaumont General Hosp., El Paso, Tex., Amer. J. Roentenol., 109, 820 2 (1970)

RISA を用いて血清を標識することにより, 血球量 を測定する方法は手技が簡単迅速で, 自動化も可能で あるら光, 繰り返し測定が可能であるが, 従来 ${ }^{51} \mathrm{Cr}$ 標識法の結果と比較して時に合致しない結果になる点 が批判されてきていた。33例の患者での測定で両法に よる相関はきわめて良好であることがわかった $(r=+$ 0.974)。 ${ }^{51} \mathrm{Cr}$ 法との差は扔拈むねきわめて小さく, 差 の大きい場合でも臨床的な価值を失わせるほど大きい 差のある例はない。臨床的な目的には手技の簡便性と いう点でRISA法で十分であると思われる。(79510)
3719 Polycythemia Vera in a Cat C. Reed, (9) et al.: Dept. of Clin. Sci., Pathol., and Clin. Pathol., School of Veterinary Med., Univ. of Calif., Davis, Calif., Amer. Vet. Med. Ass. J., 157, 85〜91 (1970)

ネコの真性多血症での臨床的, 生化学的, 病理学的 所見が記載されている。血液学的所見は二次性ではな い著明な多血症であることを示している。 ${ }^{51} \mathrm{Cr}$ 法で直 接測定した赤血球量は明らかに増加しているが血墏量 は正常であった。また血液の酸素飽和度も ${ }^{51} \mathrm{Cr}$-赤血 球の寿命の半減期も正常であった。 ${ }^{59} \mathrm{Fe}$ 回転の研究は 造血の著明な促進と赤血球の ${ }^{59} \mathrm{Fe}$ 取りこみの增加を 示している。剖検で最も目立つ所見は造血能の亢進で あった。実験にはビタミンCを含む ACD-抗凝固剤添 加血に ${ }^{51} \mathrm{Cr}$ ークロム酸ソーダを加えてラベルした赤血 球を使用。鉄代謝は ${ }^{59} \mathrm{Fe}$-クエン酸鉄で調べた。

(78668)
3720 Changes of the Apparent ${ }^{3} \mathbf{H O H}$, ${ }^{82} \mathrm{Br},{ }^{125} \mathrm{I}$ Human Albumin and ${ }^{51} \mathrm{Cr}$ Red Blood Cell Dilution Volumes before, during and after Operation in Human Subjects

E. Kragelund: Isotope Lab., Med. Dept. F., Gentofte Hosp., Copenhagen, Denmark, Ann. Surg., 172, 116 24 (1970)

術中術後の ${ }^{3} \mathrm{HOH},{ }^{82} \mathrm{Br},{ }^{125} \mathrm{I}$ 一トアルブミンおよ び ${ }^{51} \mathrm{C}$ - 赤血球容積の 変化を大きな腹部手術を受けた 16名について希釈法で測定した。 ${ }^{3} \mathrm{HOH},{ }^{82} \mathrm{Br}$ の見か けの容積は術中術後同じように増加する。これは大量 に産生された内因性水の大部分拈よび攝取水分の過剩 量が体内に保有されるためであろ 5 。 ${ }^{82} \mathrm{Br}$ 容積は術後 より術前のほうが一定しており，バラッキは約 $8 \%$ 。 術後短時間の血獎量は変わらない。胃液中への ${ }^{125} \mathrm{I}$ 排 泄は術後ふえるが, 小腸で再吸収され尿中に出るので あろ5。術後赤血球容積の減少する傾向が認められた が, わずかに高張な液の注射で赤血球が縮むためと思 われる。

\section{Relative Labeling of Leukocytes,}

Erythrocytes and Platelets in Human Blood by ${ }^{51} \mathbf{C r}$ H.J. Eyre, et al.: Human Tumor Cell Biol. Branch, National Cancer Inst., National Inst. of Health, Bethesda, Md., Blood, 36, 250 $\sim 3$ (1970)

${ }^{51} \mathrm{Cr}$ による末梢血球の relative labeling を, ショ 糖密度勾配により分離しオートラジオグラフィを用い て测定した。その結果, 大リンパ球と単球は小リンパ 球や顆粒球よりもかなり多くラベルされることがわか った。赤血球や血小板のラベルは比較的少ない。この ラベルされ方の相違は, 白血球の kineticsを研究す るために ${ }^{51} \mathrm{Cr}$ を用いたときのデータを評価する5え で重要である。

(79279) 
3722 Determination of Unsaturated

Iron-binding Capacity of Serum Using Resin Sponge Adsorbents T. Matsubara, et al.: Second Dept. of Internal Med., Kumamoto Univ. School of Med., Kumamoto, Clin. Med., 77, 24〜6 (1970)

Irosorb-59 kit を使 5 と不飽和鉄結合能 (UIBC) 值 が他の方法より高くでる原因を調べ，比色滴定法と一 致する值を与える改良法について述べている。ふ置温

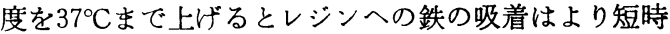
間で平衡に達し結果も正確になる。人工的な鉄飽和血 清を用いたときのレジンの摄取率との逆比から計算し た補正係数を用いたのが改良の第 2 点。この係数を使 うと UIBC 值は低くなり比色滴定法に良く一致する。 血清を飽和させるため過剩の鉄イオンを加えてる結果 は不変で，また結合鉄のレジンへの吸着やふ置中の結 合鉄とクエン酸アンモン第 2 鉄間の鉄交換は無視でき る。 (78890)

\section{Estimation of Spleen Size by}

Radioactive Scanning M. Greenberg, et al.: Lemuel Shattuck Hosp., Tufts Univ. School of Med., Boston, Mass., Gastroenterol., 58, 1024 (1970)

脾サイズの客観的計測は, 診断にも治療結果の判定 にも有用である。剖検で得た 20 例の脾を ${ }^{99 m} \mathrm{Tc}$ 溶液で 標識し，多方面よりスキャンを行なった。このスキャ ソは随円型に近似し, $V=4 / 3 \pi a b^{2}$ ( $a, b$ は長, 短径)上 り脾容量を算出した。各スキャンごとの最大長径の $1 / 2$ を $a$ とし， $b=A / \pi a$ ( $A$ はプラニメトリーによる面積) より $b$ を算出した。最大拈よび最小の断面積を有する 脾スキャンの平均值より得た值は， $r=+0.77$ で脾重 量とよく一致した。 $2 \mathrm{mCi}$ の ${ }^{99 m} \mathrm{Tc}_{2} \mathrm{~S}_{7}$-コロイド投与 後 8 例の患者のスキャンを行ない, かつ脾剔を行なっ

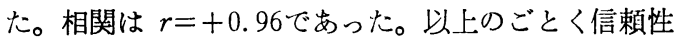
の高い測定法が確立された。

(78862)
3724 Plasma Level of ${ }^{57} \mathrm{Co}-$ Vitamin $\mathbf{B}_{12}$ as (9) an Adequate Substitute for the Schilling Test A.A. Sherman, et al.: Morrisania Hosp., Bronx, New York, J. Nucl. Med., 11, 361 2 (1970)

テストの 25〜26時間前までに 2 回 $\mathrm{B}_{12}$ を与えたのち $1 \mu \mathrm{Ci}($ 約 $1 \mu \mathrm{g})$ の ${ }^{57} \mathrm{Co}-\mathrm{B}_{12}$ を経口投与し 8 時間後の 血嶈 ${ }^{57} \mathrm{Co}-\mathrm{B}_{12}$ レベルを119症例で155回にわたり測定, 同時に Schilling テストを行ない診断に必要な臨床デ 一夕も十分に集め, 両試験の結果を比較した。血漿 ${ }^{57} \mathrm{Co}$ - $\mathrm{B}_{12}$ レペルを測定する方法は吸収不全症候群では值 にずれがあるが，155 回測定の5ち 147 回は診断可能 であり，十分 Schilling テストの代用になりうること がわかった。失禁状態にある患者にるカテーテルを使 うことなく適用でき，また腎疾患のある人にも行なう ことができる。

(78135)
3725 Spleen Scanning Using ACDdamaged Red Cells Tagged with ${ }^{51} \mathrm{Cr}$ K. Mayer, et al.: Sloan-Kettering Inst. for Cancer Res., New York, J. Nucl. Med., 11, 455 8 (1970)

${ }^{51} \mathrm{Cr}$ でラペルした ACD-damaged 赤血球を使って 精度良く脾臓のスキャニングを行なうことができる。 これによって脾臓の大きさや位置を決めることがで き，さらにある一定の大きさの粒子を肝や骨髄，脾臟 がどのぐらいの割合で領食しているかを比較すること もできる。この方法による10症例の検討結果を Table にまとめてある。

(78705)
3726 The Distribution Volume of ${ }^{82} \mathbf{B r}^{-}$

(9)

as a Measurement of the Extracellular Fluid Volume in Normal Persons A. Leth, et al.: Med. Dept., Diakonissestiftelsen, Copenhagen, Denmark, Scad. J. Clin. Lab. Invest., 25, 291 7 (1970)

正常人の ${ }^{82} \mathrm{Br}$ 分布プール容積（細胞外液量）を測 定した。平衡に達与るまでの時間は ${ }^{82} \mathrm{Br}$ 経口投与の 場合は 6 時間, 静注の場合は 4 時間であった。赤血球 中にはいったり尿中に山た ${ }^{82} \mathrm{Br}$ の補正は重要である が，血漿タンパクや Gibbs-Donnan 効果に対する補 正は必要ない。この方法を用いて測定した分布プール 容積の再現性は, 経口投与後 6 時間の場合 標準 偏 差 $0.547 \mathrm{l} / \mathrm{m}^{2}$ (体表面積) であり，静注後 4 時間の場合の

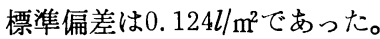

3727 Renal Scanning for Detection of (10)(7)

Renovascular Hypertension V.J. DiOrio, Jr., et al.: Dept. of Rad. Section of Nuclear Med., Indiana Univ. Med. Center, Indianapolis, Ind., Amer. J. Roentgenol., 109, 769 75 (1970)

腎血管性高血圧症に拈ける ${ }^{197} \mathrm{Hg}$-chlormerodrin 腎 スキャンの診断的価值を，15か月間43例につき検討し た。スキャンの結果を IVP, 腎動脈撮影, 血漿レニ ン值などと比較すると，手術所見では正常スキャンの ものは20例いずれも，手術で治すべき昰例でなかっ た。この中にはスキャン以外の所見はいずれも異常を 示した 1 例子ある。異常スキャンの 23 例では, 20例中 19例に動脈像と所見がよく一致し，17例中10例に血獎 レニン值と， 5 例中 3 例に分腎機能検査と一致した。

(79504) 
3728 Scintigraphic Differential Diagnosis (10)(7) of Kidney Masses with Two Tracers G. Tori, et al.: Dept. of Nuclear Med., Univ. of Bologna, Verona, Italy, Min. Med., 61, 2502 18 (1970)

${ }^{197} \mathrm{Hg}$ または ${ }^{203} \mathrm{Hg}$-neohydrin および ${ }^{99 m} \mathrm{Tc}$-pertechnetateを用い, 成人拉よび小児腎腫湯 40 例につき シンチグラフィを行なった。ラジオテクネシウムを用 いたときは，一般にその物質の拡散の増減により，悪 性か良性かを解釈する。この原則には多少の例外があ るが, 非常に簡単で, 迅速であり, 状態の悪い患者で も行ないうることがその価值を高めている。

(79636)
3729 Dual Isotope Pancreatic Imaging (11)(7)(2) Utilizing the Anger Camera and ${ }^{99 m} \mathbf{T C}$ Sulfur Colloid D.A.Bergeron, et al.: Nucl. Med. Service, Public Health Service Hosp., San Francisco, Calif., Amer. J. Roent genol., 109, 764 8 (1970)

Pho Gamma III は ${ }^{75} \mathrm{Se}$-セレノメチオニンの膡スキ ヤンに良い装置である。 ${ }^{99 m} \mathrm{Tc}$-硫化コロイドの肝スキ ヤンを同時に行ない, ${ }^{75} \mathrm{Se}$ 一レノメチオニンのスキャ ンから肝のイメージを差し引いて膆を明膫にすること るできる。これら全部のスキャンを読影に用いれば ${ }^{99 m} \mathrm{~T} \mathrm{~T}$ 一硫化コロイドによる脾の像は邪魔にならない。 この方法で障害影のないきれいな膵を描出することが できる。

(79503)
3730 Tetrameric Structure and Con(11)(6) formation of Heat-microaggregated Human Serum Albumin J.Kirschbaum: Squibb Inst. for Med. Res., New Brunswick, N.J., $J$. Pharm. Sci., 59, 854〜6 (1970)

${ }^{131} \mathrm{I}$ 標識熱小凝集血清アルブミンは，肝血流量の測 定に用いられる。この分子量は 273,000 , 沈降係数 8.6 $\mathrm{S}$ であった。もとの人血清アルブミンの分子量 67,000 (4. $6 \mathrm{~S})$ から，4 分子重合体と考元られ，薬剤添加ま たは $\mathrm{pH}$ 低下により 4 つのサブュニットに分解する （分子量72〜76,000, $4.7 \mathrm{~S}$ ）が，このサブニニットは 免疫学的方法でもとのアルブミンと異なった構造をも つことがわかった。もとの粒子径は， $50 \times 50 \times 200 \AA$ と $50 \times 100 \times 100 \AA ̊$ の間にある。

(78647)
3731 The Importance of Liver and (11)(7) Spleen Scans with ${ }^{99 m}$ Tc and ${ }^{113 m}$ In in Paediatric Pathology G.C. Mussa, et al.:

Paediatrics Clinic, Univ. of Turin, Minerva Pediatrica, 22, 919〜32 (1970)

小児科患者の肝, 脾疾患の診断にカラースキャンを 行なった。 ${ }^{99 m} \mathrm{Tc}$ と ${ }^{113 m} \mathrm{In}$ を使用し, 画像の改良とと もに, 被曝線量の減少を目的とした。15例の症例を検 討した結果を報告する。そして最後にこの近代的方法 の有用性を強調した。

(79298)
3732 Detection of Postoperative Venous (12)(7) Thrombosis and Effectiveness of Prophylactic Measures M.J. Tsapogas, et al.: Dept. of Surg., Albany Med. College of Union Univ., N.Y., Arch. Surg., 101, 149 54 (1970) ${ }^{125} \mathrm{I}$ ーフィブリノーゲン法は深在性静脈血栓の早期診 断にあたり敏感な，かつ正確な方法と考えられてい る。本法を用いて大手術を受けた成人 40 例に打いて㭘 索を行なった。40例のうち20例では，術中扰よび術後 に静脈のうっ滞を軽減し血栓形成を防止する予防手段 が講じられたが，これらの例では静脈血栓形成をみな かった。対照20例では 6 例 (30\%) に術後血栓形成が 認められた。

(79427)

\section{Detection of Thrombosis with (12)(7)} Iodine-125 Fibrinogen. Data Reassessed J.R. D'Brien: Portsmouth and Isle of Wight Area Pathology Service, Portsmouth, Lancet, 2, 396 8 (1970)

${ }^{125} \mathrm{I}$-フィブリノーゲン注入と下肢スキャンニング法 は静脈血栓の検出法としてすぐれた方法である。著者 はデータの新しい分析法を考案し臨床例に応用した。 本法では，血栓の存在する側で記録された放射能力ウ ソトには，血栓のある静脈ならびに他の静脈中のほぼ 正常量循環血液量と由来するカウントが混じっている と仮定し，記録された放射能カウントより当該部の上 部, 下部あるいは反対側のカウントより推測される正 常カウントを差し引く。その過剩カウントの変化を血 栓第 1 日目のカウントに対する百分率で示す方法は, フィブリン沈着量の変化を最す正確に反映する。 
3734 First Results with a Radio(12)(7) iodinated Lipid Tracer in Pulmonary Physiopathology. Scintigraphic and Metabolic Studies and Pulmonary Distribution G. Pescetti, et al.: Dept. of Med., Univ. of Turin, Saluggia, Minerva Med., 61, 2519 37 (1970)

肺脂質代謝の解明に，新しく ${ }^{131} \mathrm{I}$ をラベルした Lipiodol 懸濁液 (Leri) を導入した。動物実験により Leri は肺で代謝され，肺に選択的な tracer であり， また他の核種よりもすぐれた肺スキャン像を得ること ができることを確認した。正常例, 肺疾患例, 計 100 例で Leri を使用し結果を報告した。

また Leriによる autohistoradiography およびその 肺組織での代謝過程の追跡は肺の脂質代謝研究方法と して将来有望と考える。

(79512)
3735 Abscess Detection by Radioactive (13)(9) Chromium Labeled Autologous white Blood

Cells M. Deysine, et al.: Dept. Surg., Hosp. for Joint Diseases and Med. Center, New York, Surg. Gynecol. Obstet., 313, 216〜20 (1970)

${ }^{51} \mathrm{Cr}$ でラベルした自己白血球を使ってウサギの実験 的膿瘍を検出する方法が開発された。このさいの脾, 肝，肺の影響はごくわずかである。自己白血球を用い ること, 赤血球の混入を防ぐこと, 白血球以外に結合 した ${ }^{51} \mathrm{Cr}$ をアスコルビン酸で不活化すること， ヘパ リンを用いて白血球の凝集を防ぐことが成功の秘決で ある。臨床への応用の可能性のあるこの膿瘍診断法は 重要である。

(79150)
3736 Radionuclide Imaging in the (17)(7)

Detection and Differential Diagnosis of Craniopharyngioma A.E. James, Jr., et al.: Div. of Nucl. Med., Dept. of Radiol., \& Radiol. Sci., Johns Hopkins Med. Inst., Baltimore, Md., Amer. J. Roentgenol., 109, 692 700 (1970)

頭蓋咽頭腫はまれに鞍部, 鞍上部にできる良性, 先 天性腫瘍である。脳スキャンでは鞍部から上方にのび る放射活性がみられる。13例の頭蓋咽頭腫中12例で脳 スキャン陽性であった。いちばんよくでるのは前部像 であるが，13例中10例では 2 方向以上でみられた。残 りの 2 例は条件が悪かった。一例の偽院性例は頭蓋咽 頭腫がまったく辕胞性であった。脳スキャンと頭蓋X 線撮影とを併用すれば他病変との鑑別は容易である。 pertechnetate- ${ }^{-99 m} \mathrm{Tc}$ を使用するさいには粘膜の摄取 を減らすためにアトロピン（1 mg 筋注）を投与すべ きである。

(79469)
3737 Serial Brain Scanning with Radio- (17)(7) active Xenon and Scintillation Camera J. Handa, et al.: Dept. of Neurosurg. \& Central Clinical Radioisotope Div., Kyoto Univ. Med. School, Kyoto, Amer. J. Roentgenol., 109, 701 $\sim 6$ (1970)

ガンマ線シンチカメラを使用し, ${ }^{133} \mathrm{Xe}$ 生食溶液を 内頸動脈に注入して脳連続シンチフォトを行なった。 これにより脳内 3 大動脈の血流動態やその異常をみる ことができた。異常所見には 2 種類ある。血管網に富 み血流の盛んな病変では注入途次のシンチは病巣部に 高い放射能を示し,ついでこれが速やかに消失し, 低放 射能部として残る。時には，はじめ全体に一様である こともある。血流の少なくない病変ではシンチにはじ め病巣が低放射能としてあらわれながら減少が緩徐で ある。本法が他の神経放射線学的検査法にとってかわ るとは思えないが，乏血管病変で得られる像はのちに 役立つことが多い。

$(79470)$

$3739{ }^{85} \mathrm{Sr}$ Scintimetry of the Hip in

Osteoarthritis and Osteonecroris W.P.

Crutchlow: Hosp. for Special Surg. Affiliated with the New York Hosp.-Cornell Univ. Med. College, N.Y., Amer. J. Roentgenol., 109, 803 12 (1970)

正常, osteoarthritis, secondary osteoarthritis を合 併あるいは合併しない osteonecrosis と診断された116 症例195股関節に対し, ${ }^{85} \mathrm{Sr}$ scintimetry を施行した。 ${ }^{85} \mathrm{Sr}$ scintimetry がX線より早く初期の osteoarthritis を実証するうえに有用であり，idiopathic osteoarthritis のうち何例かは spontaneous osteonecrosis が以 前に存在したことに起因するものであろうということ を示唆する根抛が提示されている。

(79508) 性ガスを使用する局所血液循環動態検查とある程度対 応するようである。 (79633) 
$3740{ }^{85 m}$ Sr Scans in Children with

Extraosseous Pathology L.D. Samuels:

Radioisotope Lab., Children's Hosp., Ohio State Univ. College of Med., Columbus, Ohio, Amer. J. Roentgenol., 109, 813〜9 (1970)

種々の軟部腫瘳を有する小巟の全身骨格あるいはそ の一部分に ${ }^{87 \mathrm{~m}} \mathrm{Sr}$ scanning を施行した。骨に接する 軟部組織悪性腫瘍の存在は, たとえ悪性腫瘍がはっき りと骨を侵食していなくても，骨に悪性型の ${ }^{87 m} \mathrm{Sr}$ uptake パターンを莣起させるかるしれない。

小児に括けるがんのスクリーニングとして, ${ }^{87 m} \mathrm{Sr}$ 骨 scan の幅ひろいまた早期の診断的応用が提唱され ている。

(79509)
3741 Placenta Previa and Placental (19)(7)

Localization J.P.Semmens: USN, Naval Hosp., Long Beach, Calif., Amer. Fam. Phys./ $G P, 2,72 \sim 9$ (1970)

前置胎盤を診断するための胎盤位置決定法には種々 あるが著者は1959年に軟部X線撮影で98\%の診断率を 報告した。しかし最近は ${ }^{131} \mathrm{I}-\mathrm{HSA}$ を用い, X線の 1/100の母体”扣よび胎児被曝線量で同程度の成績を得 ている。 ${ }^{51} \mathrm{Cr}$-赤血球 や ${ }^{99 m} \mathrm{Tc}-\mathrm{HSA},{ }^{132} \mathrm{I}-\mathrm{HSA}$ ○よ い。血管撮影もよいが装置が大がかりになる。ドップ ラ一法 (音波探知器法) は大出血をしているときや分 婏時等他の方法が間に合わないときによいが30〜 40\% の誤診がある。超音波B スコープ法もよい。羊膜造影 法もよく，これを用いると胎児が造影剂をのむので胎 児の生死が判定できる。サーモグラフィは50\%の診断 率である。

(79644)

\section{Placental Imaging with Indium-}

(19)(7)

$113 m$ F.S. Mishkin, et al.: Dept. of Radiol., Indiana Univ. Med. Center, Indianapolis, Ind., Amer. J. Roentgenol., 109, 776 9 (1970)

生物学的にも物理的にもすぐれた ${ }^{113 \mathrm{~m}} \mathrm{In}$ を用いる とミリキュリー量の投与による子宮, 胎盤掞よび周囲 血管を明瞭に描出することができ, 従来のアイソトー プよりよい。妊娠第 3 期出血76例, 妊娠第 2 期で羊膜 穿剌を行なうためのもの 3 例, 計79例の胎盤シンチグ ラフィを行なった。追跡例75例中71例に正しく胎盤の 位置が推定でき，95\%の診断率である。前置胎盤16例 中 1 例が誤診, 前置胎盤でなかったるの58例中 3 例は 前置胎盤と診断し誤診であった。

(79505)
3743 Abdominal Lymph Node Scinti- (21)(7)(15) scanning with Radioactive Gold $\left({ }^{198} \mathbf{A u}\right)$ for Evaluation and Treatment of Patients with Lymphoma A.W. Pearlman: Radiation Therapy Div. of Dept. of Radiol., Univ. Hosp., New York Univ. School of Med., Amer. J. Roentgenol., 109, 780〜92 (1970)

腹部リンパ節の ${ }^{198} \mathrm{Au}$-コロイドを用いるスキャンは リンパ腫症に対し臨床的に有効な検査法であり，X線 リンパ管造影々解剖学的にも病理学的にもよく一致す る。シンチスキャンはリンパ腫の進度決定や治療計画 に有用な情報を与える。また治療中, 治療後のスキャ ソがX線リンパ管造影の所見ともよく一致し，放射線 治療の効果判定に役立つ。リンパ腫患者のルーチン検 查で症状のない腹部リンパ節病栄を検出でさる。すな わちリンパ腫症にはシンチスキャンを第一にスクリー ニング検査として行なうとよく，スキャンから得られ る情報が少ないときは，X線リンパ管造影などの検査 を行ならとよい。 (79506)

\section{$3744{ }^{75}$ Se-Selenomethionine Isotope} (21)(7) Lymphography in Lymphoma: Correlation with Lymphangiography J.T. Ferrucci, Jr., et al.: Dept. of Radiol., Harvard Med. School, Boston, Mass., Amer. J. Roentgenol., 109, 793〜802 (1970)

静注した ${ }^{75} \mathrm{Se}$ セレノメチオニンがリンパ腫に集積 しこの腫瘍のシンチグラフィが可能である。X線リン パ管造影により進度を決定したリンパ腫33例にこの簡 単で苦痛の少ない検查を行ない診断率を検討した。X 線リンパ管造影の所見を標準としてみるとシンチグラ フィで陰性でも病巣がないとはいえないがシンチグラ ムに異常が証明されたとさには70〜80\%病巣の存在が 疑える。異常シンチグラムが得られた場合にはこれを X線リンパ管造影に替えて進度決定に利用することは 十分可能である。
(79507)
3745 Jejunal Intussusception Demon- (22)(7) strated by Tc-99m Pertechnetate and Abdominal Scanning D.O. Duszynski, et al.: Dept. of Radiol. \& Surg., Children's Hosp., Buffalo, N.Y., Amer. J. Roentgenol., 109, 729 32 (1970)

Peutz-Jeghers 型のポリープによる空腸重積症を ${ }^{99 m} \mathrm{Tc}$ 静注後の腹部スキャンにより証明した。患者は 16才の男で 2 年前より費血があった。これまでの何回 かの消化管 X線検査では器質的疾患は認められなかっ たがある時期の腹部単純撮影で左上部の小腸ループに ガス貯留を認めた。 ${ }^{99 m} \mathrm{Tc}$ による腹部スキャンで，そ の部分で uptake の増加を認めたが食後の胃の拡張の ため,さらに 1 時間半後に再スキャンを行なったとこ ろ, 下腹部中央から左上腹部に扇形に攝取増大部分を 認めた。これは重積部分に行なっている腸間膜の血管 を表わしているものと思われる。手術により，空腸中 央部の 2 個の大きなポリープによる12インチの腸重積 が認められた。
(79472) 


\section{Pilot Study of Oral Combined} ${ }^{125}$ I-Triether and ${ }^{131}$-Triolein to Steatorrhea in Man J. Cooksey, et al.: Clin. Res. Center, Univ. of Illinois Hosp., Chicago, Ill., Gastroenterol., 58, 939 (1970)

人間の脂肪吸収の標識として ${ }^{125} \mathrm{I}$-trioleyl glyceryl ether ( ${ }^{125} \mathrm{I}$-triether) が適当か否か検討した。13人につ いて（5ち 5 人は吸收障害患者） ${ }^{131} \mathrm{I}$-triolein と ${ }^{125} \mathrm{I}$ triether を含む試験食を与えた。 ${ }^{125} \mathrm{I}$ の全回収率は93 〜104\%で尿に 7〜48\%， ${ }^{131} \mathrm{I}$ の糞中回収率は0.7〜32 \%であった。 ${ }^{125} \mathrm{I}$-triether に基づいた ${ }^{131} \mathrm{I}$ の回収率と 実際に判定した ${ }^{131} \mathrm{I}$ 回収率の比は正常人で1. 1〜1.8, 患者で0.9〜2.3であった。糞便間の ${ }^{125} \mathrm{I}$-triether に基づ いた: ${ }^{-131}$ I の排泄はおのおの 13〜 72\%拉よび 40〜380\% であった。尿中排泄からみた ${ }^{131} \mathrm{I}$ の吸収率は大で不定 であり，各個人の䔬便間排泄率も非常に不定で，脂肪 吸収の標識物として ${ }^{125} \mathrm{I}$-triether は適当でない。

(78858)
3747 Validation of the Krypton-85 Gastric Mucosal Blood Flow Method $H$. Sosin, et al.: Dept. Surg., Univ. of Minnesota Med. School, Minneapolis, Minn., Gastroenterol., 58, 995 (1970)

放射性不活性ガスによる組織血流量の測定は, 党醒 した動物で，連続的に测定ができる点で他法よりもす ぐれている。 ${ }^{85} \mathrm{Kr}$ による胃粘膜血流量を ${ }^{86} \mathrm{Rb}$ による 方法と比較検討した。 $5 \mathrm{~cm}$ 径の胃壁を一本の動脈とカ ニューレを入れた静脈を残して止血鉗子で保持し， $\beta$ カウンターで種々濃度の ${ }^{85} \mathrm{Kr}$ 注入時の 粘膜面の同位 元素の減衰曲線を求めた。 ${ }^{86} \mathrm{Rb}$ について 6 大動脈希 釈曲線を求め, 胃壁を粘膜, 粘膜下層, 漿膜筋層に分 けそれぞれの ${ }^{86} \mathrm{Rb}$ 濃度からそれぞれの血流量を計算 した。その結果胃粘膜血流量は ${ }^{85} \mathrm{Kr},{ }^{86} \mathrm{Rb}$ の各法で ほぼ一致し ${ }^{85} \mathrm{Kr}$ 法による胃粘膜血流量测定は妥当な ものである。

\section{Gastric Clearance of Pertechnetate (22)} $\left(\mathrm{C}_{\mathrm{T}}\right)$ as a Measure of Human Gastric Secretion J.G. Bickel, et al.: Div. of Gastroenterol., Univ. of Colorado School of Med., Denver, Col., Gastroenterol., 58, 1035 (1970) $\mathrm{Na}^{99 m} \mathrm{TcO}_{4}$ によるクリアランス (Tc) は胃粘膜の 分泌能の良い指標となる。人について $\mathrm{C}_{\mathrm{Tc}}$, 胃液分泌 量, 胃液イオン量の関係を検討した。7人について betazole 刺激下に $\mathrm{C}_{\mathrm{Tc}}$ を測定した。 $\mathrm{Na}^{99 m} \mathrm{TcO}_{4} 0.9$ $\mathrm{mCi}$ を投与後 $5 \mu \mathrm{Ci} / \mathrm{min}$ を持続静注し血中レベルを 一定に保った。 ${ }^{99 m} \mathrm{TcO}_{4}, \mathrm{Cl}^{-}, \mathrm{K}^{+}$の壁細胞性，非壁細 胞性由来の計算は Makhlouf の原理に従った。全胃ク リアランス $\left(\mathrm{C}_{\mathrm{TcT}} \mathrm{T}\right)$ および壁細胞クリアランス $\left(\mathrm{C}_{\mathrm{Tcp}}\right)$ をそれぞれの分時分泌量 $\left(\mathrm{V}_{\mathrm{T}}, \mathrm{V}_{\mathbf{p}}\right), \mathrm{Cl}^{-}$分泌量 $\left(\mathrm{Cl}_{\mathrm{T}}^{-}\right.$, $\left.\mathrm{Cl}_{\mathrm{p}}^{-}\right), \mathrm{H}^{+}$分泌量と比較した。相関係数は $\mathrm{C}_{\mathrm{TcT}}$ と $\mathrm{V}_{\mathrm{T}}$ が0.850, C $\mathrm{C}_{\mathrm{Tep}}$ と $\mathrm{H}^{+}$が0.909, $\mathrm{C}_{\mathrm{Tcp}}$ と $\mathrm{Cl}_{\mathrm{p}}^{-}$が 0.898 で, $C_{\text {Tep }} 55 \pm 8 \mathrm{ml} / \mathrm{min}$ が $\mathrm{H}^{+} \mathrm{meq} / \mathrm{min}$ に相当し, $\mathrm{C}_{\mathrm{Tep}} 7 \pm 1 \mathrm{ml} / \mathrm{min}$ で $\mathrm{H}^{+}$は 0 になる。このことは $\mathrm{H}^{+}$ の再吸収が関係している可能性もある。（78864）
3749 The Ashing Technique as a More (22)(3) Precise Method for the Radioassay of ${ }^{51} \mathrm{Cr}$ in Feces D.H. Kuiper, et al.: Univ. of $\mathrm{Mi}$ chigan, Ann Arbor, Mich., J. Nucl. Med., 11, 527〜9 (1970)

${ }^{51} \mathrm{Cr}$ 標識赤血球を用いて腸管からの出血量を測定す るさい，䨢便をホモジネートにして ${ }^{51} \mathrm{Cr}$ 放射能を测 定する方法と，䔬便を全部灰化して計測する方法を比 較した。24時間霬便について検討したところ，夷化法 のほうがはるかにまさって扣り, 標準偏差 (S.D.) の 比較で雪化法 S.D. は 3.0 であるのにホモジネート法 では32.0であった。灰化法では量を縮少して濃縮物に できること，それによってサンプルあたりのカウント が高くなり，計測誤差が少なくなることが原因であ る。

\section{The Visualization of Meckel's (22)(7) Diverticulum with ${ }^{99 m}$ Tc-Pertechnetate} T.C. Jewett, Jr., et al.: Dept. of Surg. \& Radiol., State Univ. of New York at Buffalo, N.Y., Surg., 68, 567〜70 (1970)

${ }^{99 m} \mathrm{Tc}$ 過酸化塩 $100 \mu \mathrm{Ci} / \mathrm{kg}$ を静注後の腹部スキャン が13か月打よび14才の小児のメッケル憩室の診断に役 立った。過塩化カリかヨウ化ソーダを前好置として投 与した。第 1 例は腹部中央に異常 uptake があり, 開 腹にて憩室を認めた。第 2 例では左上腹部に異常 uptake があり，手術で巨大な胃粘膜を有する唕室が確 認された。メッケル喤室は小児の消化管出血の原因の 1つで，異所性の胃粘膜に接した回腸の消化性潰瘍か ら出血する。 ${ }^{99 m} \mathrm{Tc}$ は胃腺の壁細胞に親和性がある。 腹部スキャンは前後扣よび側方向から投与後 30 分拈上 び 3 時間で行ならのがよく，コントラストの高いもの が憩室内の摄取増大領域の描出に有効である。

(79619)
3751 Radioimmunoassay of Rat Growth (23)(4) Hormone E. Dickerman, et al.: Dept. Physiol. ‘ Michigan State Univ., E. Lansing, Mich., Fed. Proc., 29, 509 (1970)

高度に純化したラット GH に Greenwood 法で ${ }^{125} \mathrm{I}$ を標識した free- ${ }^{125} \mathrm{I}$ はセファデックスG50で分け, タ ンパク部分をG100で分画したところ 3 つの peakを得 た。2 番目の山が免疫学的に最も potency がある。特 異性の高いサルの抗ラットGH と抗猿羊 ガンマグロブ リンを使用して NIAMD-Rat・GH-RP-1 を standard とした。ラット下垂体 homogenate, ラット血漿は standard と一致した抑制曲線となり，ハムスター，モ ルモットの下垂体 homogenate や血漿, 羊豚 GH な どすべて standard curve に一致した。ラットの prolactin, LH，FSH との交叉反応はなかった。下垂体除 去ラットの血漿では $\mathrm{GH}$ は証明し得ず，甲状腺除去 や去勢で下垂体 GH は減少, thyroxine や testosterone は GH 值を増加した。
(79162) 